\title{
Diversity of pathogenic Pseudomonas isolated from citrus in Tunisia
}

\author{
Maroua Oueslati ${ }^{1}$, Magdalena Mulet ${ }^{2}$, Mohamed Zouaoui ${ }^{1}$, Charlotte Chandeysson ${ }^{3}$, Jorge Lalucat ${ }^{2,4}$, \\ Mohamed Rabeh Hajlaoui ${ }^{5}$, Odile Berge ${ }^{3}$, Elena García-Valdés ${ }^{2,4}$ and Najla Sadfi-Zouaoui ${ }^{*}$ (i)
}

\begin{abstract}
The damages observed in Tunisian citrus orchards have prompted studies on the Pseudomonas spp. responsible for blast and black pit. Prospective orchards between 2015 and 2017 showed that the diseases rapidly spread geographically and to new cultivars. A screening of Pseudomonas spp. isolated from symptomatic trees revealed their wide diversity according to phylogenetic analysis of their housekeeping $r p o D$ and $c t s$ genes. The majority of strains were affiliated to Pseudomonas syringae pv. syringae (Phylogroup PG02b), previously described in Tunisia. However, they exhibited various BOX-PCR fingerprints and were not clonal. This work demonstrated, for the first time in Tunisia, the involvement of Pseudomonas cerasi (PG02a) and Pseudomonas congelans (PG02c). The latter did not show significant pathogenicity on citrus, but was pathogenic on cantaloupe and active for ice nucleation that could play a role in the disease. A comparative phylogenetic study of citrus pathogens from Iran, Montenegro and Tunisia revealed that P. syringae (PG02b) strains are closely related but again not clonal. Interestingly P. cerasi (PG02a) was isolated in two countries and seems to outspread. However, its role in the diseases is not fully understood and it should be monitored in future studies. The diversity of pathogenic Pseudomonas spp. and the extension of the diseases highlight that they have become complex and synergistic. It opens questions about which factors favor diseases and how to fight against them efficiently and with sustainable means.
\end{abstract}

Keywords: Citrus, Cultivars, Pseudomonas syringae, rpoD, Pathogenicity

\section{Key points}

- Citrus blast and citrus black pit were spread to new areas and cultivars in Tunisia.

- In addition to Pseudomonas syringae (Phylogroup PG02b), Pseudomonas congelans (PG02c) and Pseudomonas cerasi (PG02a) are now involved in the disease.

- A group of closely related strains is responsible for the disease in Tunisia, Montenegro and Iran.

\footnotetext{
*Correspondence: najla.sadfi@fst.utm.tn

${ }^{1}$ Laboratoire de Mycologie, Pathologies et Biomarqueurs (LR16ES05),

Département de Biologie, Université de Tunis-El Manar, 2092 Tunis, Tunisie

Full list of author information is available at the end of the article
}

\section{Introduction}

Pseudomonas syringae has a huge impact on our scientific understanding of microbial pathogenicity, and continues to cause economically important plant diseases to both woody and annual crops (Lamichhane et al. 2015). It represents not only the first plant pathogenic bacteria but also the top of all time pathogen charts including fungi and oomycetes (Mansfield et al. 2012). Furthermore, in three consecutive years (January 2015 to July 2018), reports of diseases caused by strains of the P. syringae species group are more frequent than those caused by any other group of phytopathogenic bacteria (Morris et al. 2019). The wide genetic diversity of $P$. syringae pv. syringae is probably the cause of its large host range (Martín- Sanz et al. 2013). Many studies have demonstrated the transmissible nature of $P$. syringae, but it is also a remarkably adaptive pathogen, isolated from 
non-agricultural sites, in astonishing substrates such as snowmelt (Monteil et al. 2011) or epilithic biofilms (Morris et al. 2007). In this context, $P$. syringae has been proposed as a potential contributing factor in the formation of rain and snowfall, shaping the water cycle on Earth due to its efficiency as ice nucleators (Morris et al. 2013; Lamichhane et al. 2014). In agriculture, the ice nucleation activity of $P$. syringae can influence the transition from the epiphytic to the endophytic phase as the damage of frost leads to the creation of openings on the surface of plants to facilitate the entry of bacteria (Xin et al. 2018). P. syringae pv. syringae specially is a potent epiphytic bacterium and under favorable environmental conditions, the bacterial population colonizing the plant can be good predictors of later endophytic populations and disease outbreaks (Hirano and Upper 2000). On citrus orchards, in the Mediterranean countries $P$. syringae is responsible for two damaging diseases including black pit and blast (Ivanović et al. 2017; Abdellatif et al. 2017). Only few studies were developed taking this problem into account. Citrus blast has been reported in Turkey (Mirik et al. 2005), Iran (Beiki et al. 2016) and Montenegro (Ivanović et al. 2017). In Tunisia, P. syringae has been described on tomato (Mensi et al. 2018), on citrus (Abdellatif et al. 2015) and it was isolated from weeds and plant debris that can be the source of inoculums to trigger citrus blast and black pit diseases (Mougou and BoughallebM'Hamdi 2016). Given the significant damages observed in the field, the quick emergence of the disease and the economic importance of citrus cultivation in Tunisia, research on these diseases has recently grown. So far, the polyphagous nature and the diversity of these bacteria as well as its adaptive and resistant capacities have been more or less under estimated in Tunisia, although several studies focused on citrus blast and citrus black pit. Only similar pathogenic $P$. syringae strains belonging to phylogroup PG02b as described by Berge et al. (2014) were described (Mougou and Boughalleb-M'hamdi 2016; Abdellatif et al. 2017). In Montenegro, strains isolated from necrotic mandarin buds have been identified as one homogenous lineage of $P$. syringae pv. syringae (Ivanović et al. 2017). On the contrary, a more open approach was used in the citrus growing provinces of northern Iran where Beiki et al. (2016) revealed that several Pseudomonas species are involved in citrus blast. The disease was caused by pathogenic $P$. viridiflava, $P$. syringae and by $P$. lurida, $P$. orientalis, $P$. simiae and $P$. moraviensis reported for the first time in the disease (Beiki et al. 2016). In the same region, a new pathogenic species from the $P$. syringae group, $P$. caspiana was isolated from citrus leaf and stems symptoms (Busquets et al. 2017). It seems that many Pseudomonas species could be involved in citrus blast and black pit and that these diseases are more complex than previously thought. In order to better understand the situation in Tunisian orchards, Oueslati et al. (2019), using a similar approach, identified two new pathogenic Pseudomonas species involved in citrus black pit disease in different Tunisian sites: P. kairouanensis and $P$. nabeulensis. In this study, we aimed to explore the diversity and population structure of the pathogenic bacteria from the $P$. syringae group on citrus in Tunisia. A large survey of main citrus production regions during three seasons allowed the isolation of 820 strains from citrus fruits, branches and leaves with black pit, gummosis and blast diseases. Several species of the P. syringae group were identified with a chemotaxonomic approach and confirmed by a phylogenetic analysis of their cts or $r p o D$ gene sequences two appropriate biomarkers for Pseudomonas spp. (Mulet et al. 2010; Sánchez et al. 2014a; Berge et al. 2014). They were characterized for some phenotypic and pathogenic traits and their genotypic diversity was studied. This study showed clearly for the first time, the spread of the disease to the Kairouan region, and that new cultivars (cvs) such as Citrus limon cv. 'Lunari,' C. reticulata cv. 'Hernandina' and C. sinensis cvs. 'Maltaise' and 'Valencia Late' are now affected by the diseases. In order to control these diseases, it will be necessary to better describe and understand the presence of the bacterial population involved and the role of their diversity.

\section{Materials and methods \\ Sampling strategy}

The main administrative governates (6) devoted to the production of citrus fruits in Tunisia were selected: Nabeul (Cap Bon Peninsula) located in the extreme north-east of the country, Ben Arous and Bizerte situated successively in the North and extreme north, Beja and Jendouba located in the north-west and Kairouan in the center of Tunisia (Fig. 1). A total of 37 orchards were chosen arbitrarily during winter and spring seasons of 2015, 2016 and 2017 (Additional file 1: Table S1). A survey sheet for each orchard and their characteristics was established. Depending on the incidence of the disease in the orchard, between 1 and 9 symptomatic trees were sampled, with fruit, leaf, twig or branch part of the tree being collected (Fig. 2 and Additional file 1: Table S1). The samples were taken from $C$. sinensis cvs.'Valencia Late,' 'Washington Navel' and 'Maltaise', C. limon cvs. 'Eurêka' and 'Lunari, C. reticulata cvs. 'Hernandina' and 'Cassar' and C. paradisi cv'Star Ruby'.

\section{Bacterial isolation}

Samples were placed separately in sterile bags before being transferred to the laboratory. For each sample, small pieces of the intermediate zone between the 


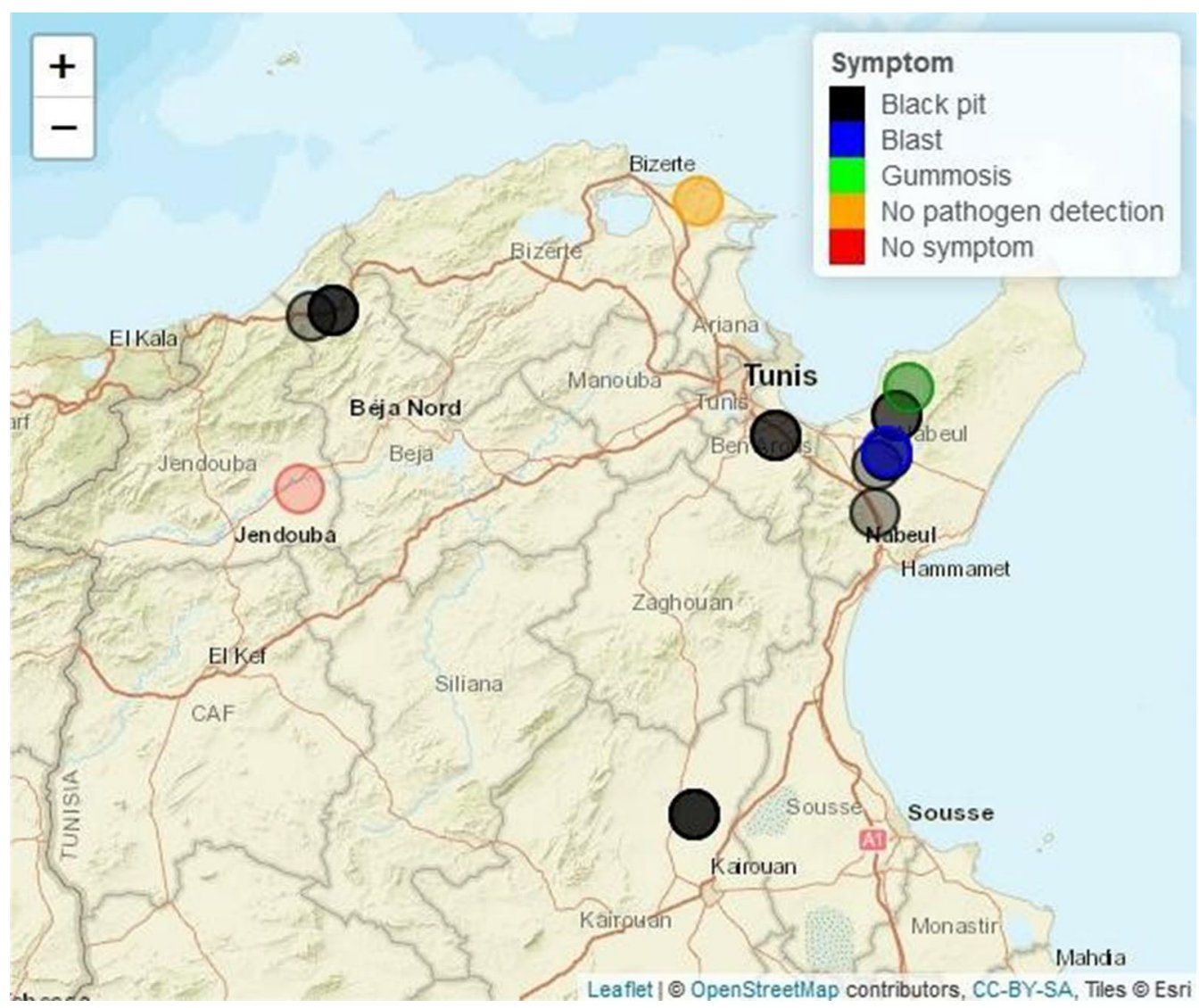

Fig.1 Geographical localization and distribution of symptoms in Tunisian governates sampled. No pathogen detection: Presence of symptoms but no isolation of P. syringae

healthy and the necrotic part were disinfected with $0.5 \%$ sodium hypochlorite and washed with sterile distilled water (SDW) macerated in phosphate buffer (K2HPO4 (BIOMATIQ): $8.75 \mathrm{~g} / \mathrm{l}, \mathrm{KH} 2 \mathrm{PO} 4$ (BIOMATIQ): $6.75 \mathrm{~g} / \mathrm{l}$ ) and vortexed for $4 \mathrm{~min}$ (Monteil et al. 2011). The liquid of the crushed material was diluted to $10^{-4}$ and $100 \mu \mathrm{l}$ of each sample were spread on the entire Trypticase Soy Agar (TSA, Biolife) and King B media (KB, Biolife) supplemented with cycloheximide SIGMA (200 mg/l), cephalexin SIGMA $(80 \mathrm{mg} / \mathrm{l})$ and Boric acid BIOMATIQ $1.5 \mathrm{~g} / 100 \mathrm{ml}$ (KBC medium). After 2 days at $28^{\circ} \mathrm{C}$, fluorescent colonies were subcultured on $\mathrm{KB}$ plates to ensure purity and pure strains were stored in $40 \%$ glycerol at $-80^{\circ} \mathrm{C}$ and on $\mathrm{KB}$ at $4{ }^{\circ} \mathrm{C}$ for short-term use.

\section{Phenotypic characterization of strains}

Colony size and morphology were determined on strains together with production of fluorescent pigments tested on King B medium (Pseudomonas agar F; Difco), and pyocyanin production tested on King A medium (Pseudomonas agar P, Biolife) (King et al. 1954). Oxidase tests were performed as previously described (Ewing et al.
1962). Strains were characterized phenotypically using API ZIM (bioMérieux) (Gruner et al. 1992) and were tested for production of syringomycin-like toxins on a minimal SRM medium (Gross 1985) that is revealed by antibiosis for Geotrichum candidum (Gross and Devay 1977; Morris et al. 2007). Ice nucleation activity (INA) of strains was characterized as previously described (Stopelli et al. 2014). Three replicates/strain of fresh suspensions adjusted to $10^{6}$ Colony-forming Unit (CFU)/ $\mathrm{ml}^{-1}$ in phosphate buffer were used in the range of temperature from 0 to $-7{ }^{\circ} \mathrm{C}$. For all phenotypic and plant tests (see below), the pathogenic strain P. syringae CC94, (Morris et al. 2000), was used as a positive control and sterile distilled water as a negative control.

\section{Antibiotic resistance}

The Pseudomonas isolates were evaluated against 25 antibiotics of different families using the disk diffusion method of Bauer et al. (1966). The antibiotics families used in the resistance test were: penicillin, (cephalosporin, carbapenem, aminopenicillin and aminosides), fluoroquinolone (ciprofloxacin, pefloxacin, ofloxacin), 


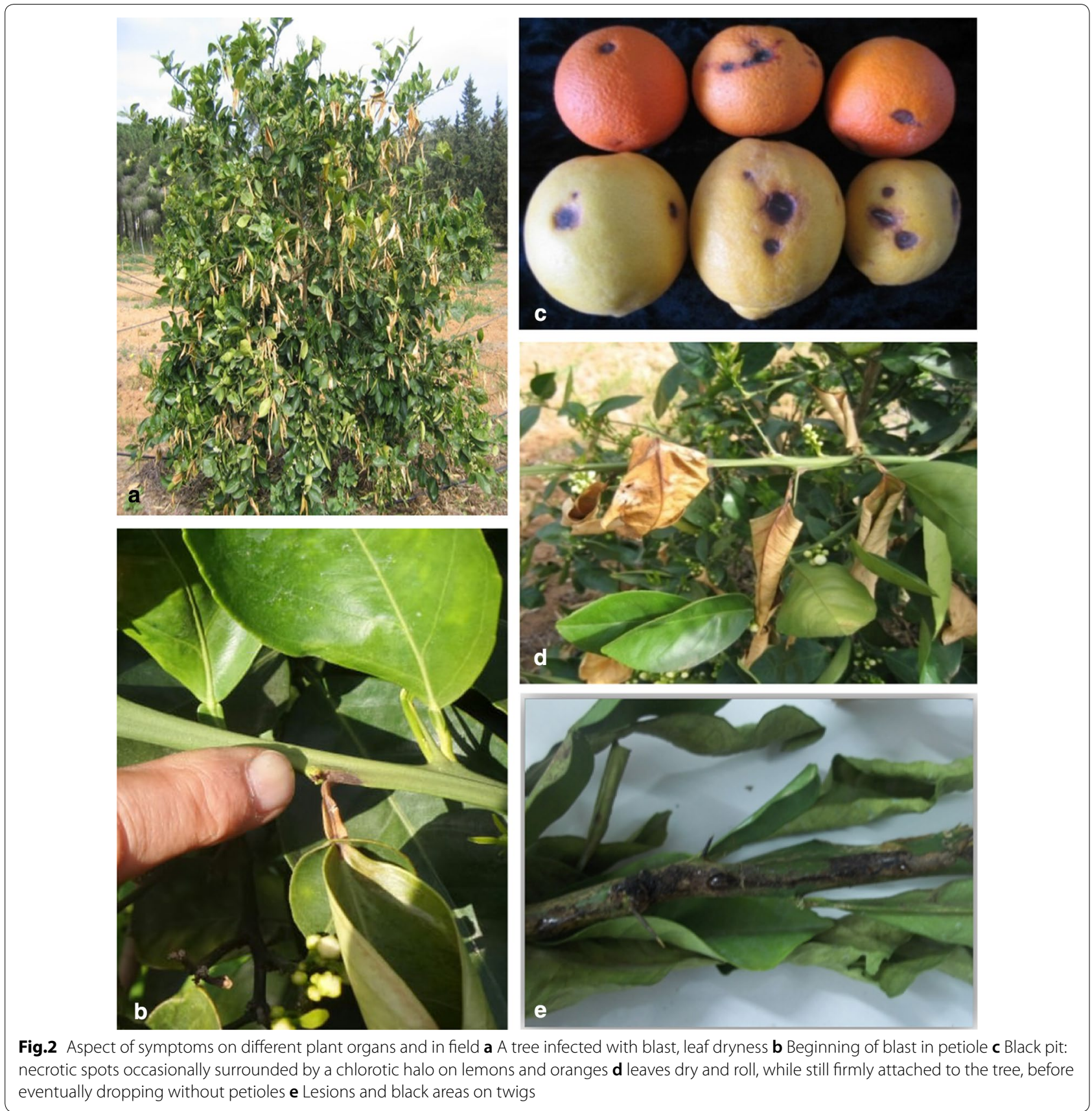

quinolone (nalidixic acid), sulfamides-trimethoprim, polypeptide, carboxypenicillin, monobactam, tetracyclines and phenicolates. Antibiotic discs were placed on nutrient agar medium (BioMérieux) previously inoculated with a pure culture of $48 \mathrm{~h}$ strains adjusted to $10^{6} \mathrm{CFU} \mathrm{ml}{ }^{-1}$. After incubation at $30{ }^{\circ} \mathrm{C}$ for $24 \mathrm{~h}$, inhibition zones were measured in $\mathrm{mm}$, comparing them with critical values of the European Committee on Antimicrobial Susceptibility Testing (EUCAST, www. eucast.org) to evaluate whether a strain was sensitive or resistant. Multiresistance classification was performed according to Magiorakos et al. (2012). Multidrug resistance (MDR) is defined as non- susceptible to at least one agent in three or more antimicrobial categories. Extensive drug resistance (XDR) is defined as nonsusceptible to at least one agent in all but two or fewer antimicrobial categories. Pandrug-resistance (PDR) is defined as non-susceptible to all agents in all microbial categories. 


\section{Strain identification \\ Matrix-assisted laser desorption/ionisation time-of-flight mass spectrometry}

Strains were identified following a chemotaxonomic approach using matrix-assisted laser desorption/ionisation time-of-flight mass spectrometry (WC MALDI-TOF MS) (Bright et al. 2002). The studied strains together with their closely related species type strains were obtained at the Scientific- Technical Services (University of Balearic Islands, Spain). Strains were cultured on LB medium at $30{ }^{\circ} \mathrm{C}$ for 24 to $48 \mathrm{~h}$. After extraction, one microliter of the extract was placed onto a spot of a ground steel plate. Each sample was covered with $1 \mu \mathrm{L}$ of matrix solution and air dried at room temperature. The measurements were carried out on an Autoflex III MALDI-TOF / TOF mass spectrometer (Bruketar Daltonics, Leipzig, Germany). Data were analyzed as previously described with an indoor database used to compare the protein profiles (Sánchez et al. 2014b).

\section{Phylogenetic analysis of strains}

The DNA extraction, primers used, PCR amplification, and DNA sequencing conditions, as well as the sequence analysis procedures were previously described (Mulet et al. 2010). Amplified products were purified with Montage PCR filter units (Millipore) (Mulet et al. 2016). An individual tree based on the $r p o D$ partial sequence alignment was generated with all studied strains (Yamamoto et al. 2000; Ghyselinck et al. 2013). A multilocus sequencing analysis (MLSA) with the concatenated three-genesequences $16 \mathrm{~S}$ rRNA (1279 nt), gyrB (794 nt), and rpoD (648 nt) was also performed for those representative strains (Mulet el al. 2012). Sequences were compared with the corresponding sequences of Pseudomonas species type strains described up until November 2018 with 203 species type strains in our in-house database. Alignments were analyzed according to Mulet et al. (2008). The gene distances were calculated, using the Jukes-Cantor method (Jukes and Cantor 1969), and phylogenetic trees were generated by neighbour-joining using MEGA5 software (Tamura et al. 2011). Sequences obtained in this study were deposited in the EMBL database. To further identify the studied strains, a phylogenetic tree was constructed using the partial sequences of the $r p o D$ gene (455 nt) using the 4 strains previously proposed (Parkinson et al. 2011; Berge et al. 2014) as reference strains to define the phylogroups PG02a, PG02b, PG02c and PG02d within the $P$. syringae species group. The 15 species type strains of the $P$. syringae group (Gomila et al. 2017) were also included in the analysis. The identity of putative P. syringae strains M5 and M47 from the Technical Center of Citrus orchard, Bni khalled region of Nabeul governate, and V2A2F14, 27, 45, 52 and 79 from
Charfeddine orchard, Bouargoub region of Nabeul governate (Table 1), was obtained by studying their phylogenetic context. Reference strains of the $P$. syringae group of bacteria were included (see the list in Additional file 1: Fig. S1) and the analyses were based on partial sequences of the citrate synthase (cts) housekeeping gene as previously described (Berge et al. 2014). Primers Cts-FP (forward): 5-AGT TGA TCA TCG AGG GCG C(AT) G CC-3 and Cts-RP (reverse): 5-TGA TCG GTT TGA TCT CGC ACG G-3 (Sarkar and Guttman 2004; Morris et al. 2010) were used for DNA amplification and primer Cts-FS (fwd): 5-CCC GTC GAG CTG CCA ATW TTG CTG A-3 for sequencing. DAMBE (version 5) was used to perform sequence-alignment and Mega (version 4) to build a neighbor-joining tree. Housekeeping gene (rpoD) sequences available from previous studies on $P$. syringae pv. syringae present on citrus in Iran (FBF strains) and Montenegro (IZB strains) were compared with our data.

\section{Nucleotide sequence numbers}

The GenBank/EMBL/DDBJ accession numbers for the nucleotide sequences reported in this study are as follows: LR214467-LR214509 for the rpoD gene, LR214451LR214466 for the 16S rRNA and LR214510-LR214525 for the gyrB gene.

\section{Tests on plants}

Pathogenicity tests were performed on lemon fruits and detached leaves of $C$. limon cv. 'Eurêka'. Fruits and leaves were dipped in a solution of sodium hypochlorite (1\% active hypochlorite) for $5 \mathrm{~min}$, rinsed three times in sterile distilled water and gently dried with filter paper. The pathogenic strain P. syringae pv. syringae KB49 (a member of phylogroup PG02b) isolated from a citrus orchard in Tunisia with black pit symptoms was used as a positive control. Strains were grown on Luria Broth medium at $28{ }^{\circ} \mathrm{C}$ for $48 \mathrm{~h}$. One or two colonies were suspended in sterile distilled water to an absorbance at $580 \mathrm{~nm}$ between 0.06 and 0.12 , which corresponds to approximately $10^{8} \mathrm{CFU} / \mathrm{ml}$. The suspensions $(10 \mu \mathrm{l})$ were inoculated either by injection with a tuberculin needle at the fruit wall or by spraying on the surface of fruits. Negative controls were treated similarly with sterile distilled water (Gilbert et al. 2010). Three fruits were inoculated for each strain as well as for the controls. After 5 days at $20{ }^{\circ} \mathrm{C}$, necroses were measured for both methods of inoculation (Iacobellis et al. 1994). For leaves, $10 \mu \mathrm{l}$ of the bacterial suspension were injected into the central veins of the abaxial side and inoculated leaves were incubated. The experiment consisted of three replicates per strain. To verify Koch Postulate, bacteria were reisolated on KB medium and BOX elements were used for DNA fingerprinting (Marques et al. 2008; Koeuth et al. 1995). 
Table 1 Origin of selected strains characterized in this study

\begin{tabular}{|c|c|c|c|c|c|c|}
\hline Strain $^{a}$ & Year of isolation & Governorate/region & Orchard & Cultivar & Organ & Symptom \\
\hline $\mathrm{BE} 12 \mathrm{~A}$ & 2017 & Beja/Nefza & M. Guennouni ${ }^{d}$ & $C^{e}$. sinensis 'Valencia Late' & Fruit & Black pit \\
\hline BE1 & 2017 & Beja/Nefza & M. Guennouni & C. sinensis 'Valencia Late' & Fruit & Black pit \\
\hline BE3 & 2017 & Beja/Nefza & M. Guennouni & C. sinensis 'Valencia Late' & Fruit & Black pit \\
\hline Iy3DA & 2017 & Ben Arous/Naasen & Ayari & C. limon 'Eurêka' & Fruit & Black pit \\
\hline ly3EA & 2017 & Ben Arous/Naasen & Ayari & C. limon 'Eurêka' & Fruit & Black pit \\
\hline ly3GB & 2017 & Ben Arous/Naasen & Ayari & C. limon 'Eurêka' & Fruit & Black pit \\
\hline Iy5HA & 2017 & Ben Arous/Naasen & Ayari & C. limon 'Eurêka' & Fruit & Black pit \\
\hline lyGA & 2017 & Ben Arous/Naasen & Ayari & C. sinensis 'Maltaise' & Fruit & Black pit \\
\hline IyGC & 2017 & Ben Arous/Naasen & Ayari & C. sinensis 'Maltaise' & Fruit & Black pit \\
\hline KB49 & 2017 & Kairouan/Sbikha & Chaabani 1 & C. sinensis 'Valencia Late' & Fruit & Black pit \\
\hline KC19 & 2017 & Kairouan/Sbikha & Chaabani 2 & C. sinensis 'Valencia Late' & Fruit & Black pit \\
\hline KC29B2 & 2017 & Kairouan/Sbikha & Chaabani 2 & C. sinensis 'Valencia Late' & Fruit & Black pit \\
\hline KC46 & 2017 & Kairouan/Sbikha & Chaabani 2 & C. sinensis 'Valencia Late' & Fruit & Black pit \\
\hline KC54 & 2017 & Kairouan/Sbikha & Chaabani 2 & C. sinensis 'Valencia Late' & Fruit & Black pit \\
\hline KC55 & 2017 & Kairouan/Sbikha & Chaabani 2 & C. sinensis 'Valencia Late' & Fruit & Black pit \\
\hline KC82 & 2017 & Kairouan/Sbikha & Chaabani 2 & C. sinensis 'Valencia Late' & Fruit & Black pit \\
\hline TRR12 & 2015 & Nabeul/Bouargoub & The Gardens & C. limon'Lunari' & Fruit & Black pit \\
\hline TRR15 & 2015 & Nabeul/Bouargoub & The Gardens & C. limon'Lunari' & Fruit & Black pit \\
\hline TRR9 & 2015 & Nabeul/Bouargoub & The Gardens & C. limon'Lunari' & Fruit & Black pit \\
\hline MTR3B & 2015 & Nabeul/Tekelsa & SOTAM ${ }^{c}$ & C. reticulata'Hernandina' & Branch & Gummosis \\
\hline E10AA & 2017 & Nabeul/Bnikhalled & Chakib & C. limon 'Eurêka' & Fruit & Black pit \\
\hline E10CA & 2017 & Nabeul/Bnikhalled & Chakib & C. limon 'Eurêka' & Fruit & Black pit \\
\hline E10CB2 & 2017 & Nabeul/Bnikhalled & Chakib & C. limon 'Eurêka' & Fruit & Black pit \\
\hline E11 & 2017 & Nabeul/Bnikhalled & Chakib & C. limon 'Eurêka' & Fruit & Black pit \\
\hline E12A & 2017 & Nabeul/Bnikhalled & Chakib & C. limon 'Eurêka' & Fruit & Black pit \\
\hline E91 & 2016 & Nabeul/Bnikhalled & Dhaouadi & C. limon 'Eurêka' & Twig & Blast \\
\hline E93A & 2016 & Nabeul/Bnikhalled & Dhaouadi & C. limon 'Eurêka' & Twig & Blast \\
\hline E9A & 2016 & Nabeul/Bnikhalled & Dhaouadi & C. limon 'Eurêka' & Twig & Blast \\
\hline EL1A & 2016 & Nabeul/Bnikhalled & $\mathrm{TCC}^{\mathrm{b}}$ & C. limon 'Eurêka' & Fruit & Black pit \\
\hline EL2 & 2016 & Nabeul/Bnikhalled & TCC & C. limon 'Eurêka' & Fruit & Black pit \\
\hline$M 5^{*}$ & 2016 & Nabeul/Bnikhalled & TCC & C. reticulata 'Cassar' & Fruit & Black pit \\
\hline M29* & 2016 & Nabeul/Bnikhalled & TCC & C. reticulata 'Cassar' & Fruit & Black pit \\
\hline $\mathrm{M} 30^{*}$ & 2016 & Nabeul/Bnikhalled & TCC & C. reticulata 'Cassar' & Fruit & Black pit \\
\hline M32* & 2016 & Nabeul/Bnikhalled & TCC & C. reticulata 'Cassar' & Fruit & Black pit \\
\hline$M 47^{*}$ & 2016 & Nabeul/Bnikhalled & TCC & C. reticulata'Cassar' & Fruit & Black pit \\
\hline V2A2F14* & 2016 & Nabeul/Bouargoub & Charfeddine & C. sinensis 'Maltaise' & Fruit & Black pit \\
\hline V2A2F15* & 2016 & Nabeul/Bouargoub & Charfeddine & C. sinensis 'Maltaise' & Fruit & Black pit \\
\hline $\mathrm{V} 2 \mathrm{~A} 2 \mathrm{~F} 27^{*}$ & 2016 & Nabeul/Bouargoub & Charfeddine & C. sinensis 'Maltaise' & Fruit & Black pit \\
\hline V2A2F45* & 2016 & Nabeul/Bouargoub & Charfeddine & C. sinensis 'Maltaise' & Fruit & Black pit \\
\hline V2A2F $52^{*}$ & 2016 & Nabeul/Bouargoub & Charfeddine & C. sinensis 'Maltaise' & Fruit & Black pit \\
\hline V2A2F79* & 2016 & Nabeul/Bouargoub & Charfeddine & C. sinensis 'Maltaise' & Fruit & Black pit \\
\hline
\end{tabular}

\footnotetext{
a Strainwith * were lost during thestudy and were no longer available to do all tests. All strains were fluorescent on KB medium and negativefor oxidase

b Technical Center of Citrus

c Tunisian Society of Modern Agriculture

d M. Guennouni:MiledGuennouni

e Citrus
} 
Cucumis melo var. cantalupensis Naud. cv. Védrantais seedlings were used as an indicator plant to estimate the level of aggressiveness (Morris et al. 2000). These parameters were assessed after infiltrating twelve seedlings at the junction of the cotyledons with $10 \mu \mathrm{l}$ of an aqueous bacterial suspension $\left(10^{8} \mathrm{CFU} \mathrm{m}{ }^{-1}\right)$ prepared from $48 \mathrm{~h}$ bacterial cultures (Morris et al. 2008). Seedlings were incubated for seven days with photoperiod of $16 \mathrm{~h}$ of light at $21{ }^{\circ} \mathrm{C}$ during the day and $18{ }^{\circ} \mathrm{C}$ during the dark period. Symptoms on seedlings were scored as follows: 0 (no symptoms), 1 (one cotyledon with necrosis or completed wilted), 2 (necrosis on both cotyledons), 3 (both cotyledons wilted and stem symptoms) and 4 (death of the entire plantlet). Pathogenicity was recorded positive when the frequency of seedlings with symptoms (F) was $>50 \%$ and aggressiveness was calculated as the mean score of symptoms $(\mu)$ (Berge et al. 2014). Sterile distilled water was used as a negative control and P. syringae CC94 as a positive control.

The capacity of strains to induce a hypersensitive response (HR) was determined in tobacco by infiltrating fully developed leaves of plants of Nicotiania tobacum L. cv. Samsun at the 10-leaf stage (bacterial suspensions of $48 \mathrm{~h}$ cultures at approximately $10^{8} \mathrm{CFU} \mathrm{ml}{ }^{-1}$ ) (Leliott et al. 1966).

\section{Results}

Thirty-seven orchards of citrus implanted in fourteen regions of six different governates located in northern Tunisia were surveyed for black pit and blast symptoms during three seasons (2015-2017). Tentative isolations of pathogenic Pseudomonas sp. were performed from 279 samples collected on symptomatic trees (Fig. 2 and Additional file 1: Table S1). The percentage of symptomatic trees in these orchards was less than $5 \%$ indicating a low incidence of disease. However in two orchards, this percentage was higher (19 and 22.5\%) showing these diseases could be very serious. It is important to perform isolation of pathogenic bacteria from orchards that will help when present, to avoid dissemination. The prevalence of the disease varies by governate (Fig. 1). In Jendouba governate, no symptoms were observed in two orchards from the Bouselem region surveyed in 2017. In the three orchards from the Ras Jbel region of Bizerte governate symptoms were observed, especially in Ras Jbel 1 orchard in 2015 (22.5\% of symptomatic trees) but pathogenic Pseudomonas sp. were not isolated from the 41 samples collected (Additional file 1: Table S1).

In Kairouan governate, found free from disease in a 2012-15 survey (Abdellatif et al. 2017), symptoms in the two orchards from Sbikha region were observed in 2017, and pathogenic Pseudomonas sp. were isolated from both of them. In Ben Arous and Beja governates, symptoms were present in all seven orchards studied however, pathogenic Pseudomonas sp. were isolated only from one orchard per governate: Ayari orchard, Naasen region of Ben Arous, and Miled Guennouni orchard, Nefza region of Beja, both surveyed in 2017. Finally, in Nabeul governate where the survey was the largest, symptoms were present in 20 orchards among the 24 visited in 6 regions during the three years of the study. In this governate, pathogenic Pseudomonas sp. was isolated from 6 symptomatic orchards located in BniKhalled (3), Tekelsa (1) and Bouargoub (2) regions (Additional file 1: Table S1).

All orchards free of symptoms were conduced following conventional methods with irrigation either by surface or drip technique. Pathogenic Pseudomonas sp. strains were isolated in $44 \%$ of conventional and $25 \%$ of organic symptomatic orchards surveyed (Additional file 1: Table S1). Our extensive study confirms the presence of symptomatic trees in many Tunisian citrus orchards and describe for the first time in 2017, symptoms in orchards of the Kairouan region (Fig. 1). Moreover this work shows that the disease affects many different citrus cultivars grown in Tunisia. A total of 820 strains were isolated from 81 symptomatic trees and based on colony morphology, 54 putative $P$. syringae strains were selected to be characterized (Additional file 1: Table S1).

\section{Strain identification}

Among the 54 putative $P$. syringae, 11 strains isolated in 2016, fluorescent on KB medium and tested negative for cytochrome c oxidase activity, were firstly identified using partial housekeeping $c t$ sene sequencing following Berge et al. (2014). Five strains from Technical Center of Citrus sharing the same BOX-PCR profile and 6 strains from Charfeddine orchards (Nabeul) were affiliated to $P$. syringae (phylogroup PG02b) and P. cerasi (phylogroupPG02a) respectively (Tables 1 and 2; Additional file 1: Fig. S1). These two species belong to the P. syringae group of bacteria (Gomila et al. 2017).

These 43 strains were tested Gram negative and they were able to grow and fluoresce on $\mathrm{KB}$ and $\mathrm{KBC}$ media. The oxidase test was positive for 13 strains and negative for 30 strains. P. syringae do not have cytochrome c oxidase and the work was focused on the 30 strains negative for oxidase (Table 1), the 15 remaining strains being kept in the study to look at their identification. WC MALDITOF MS protein profiles were obtained for all 43 strains which were identified with good confident values $(\geq 2)$ in the Biotyper database (Table 2 and Additional file 1: Table S2).

Their chemotaxonomic analysis classified all of them but one, in the fluorescent Pseudomonas lineage of Mulet et al. (2010) classification. The 13 oxidase positive strains were identified to P. lactis (2 strains from the same tree), 
Table 2 Identification and classification of strains based on WC-MALDI-TOF MS and on phylogenetic analysis of housekeeping genes sequences

\begin{tabular}{|c|c|c|c|c|c|c|c|c|c|}
\hline \multirow[t]{3}{*}{ Strain $^{a}$} & \multicolumn{2}{|c|}{ WC-MALDI-TOF-MS'b } & \multicolumn{4}{|l|}{ Sequences identity } & \multirow{3}{*}{$\begin{array}{l}\text { Final identi- } \\
\text { fication }\end{array}$} & \multirow[t]{3}{*}{ P. s. phylo-group ${ }^{f}$} & \multirow{3}{*}{$\begin{array}{l}\text { Box- } \\
\text { PCR } \\
\text { profileg }^{\text {p }}\end{array}$} \\
\hline & \multirow[t]{2}{*}{ Best match with } & \multirow[t]{2}{*}{ Score value $^{d}$} & \multicolumn{2}{|l|}{$\begin{array}{l}\text { ctsorrpo } D \text { gene } \\
\text { sequence }\end{array}$} & \multicolumn{2}{|l|}{$\begin{array}{l}\text { Concanated gene } \\
\text { sequence }^{\mathrm{e}}\end{array}$} & & & \\
\hline & & & Closest type strain & $\%$ & Closest type strain & $\%$ & & & \\
\hline BE12A & P. congelans & 2.09 & P. congelans(rpoD) & 98.0 & P. congelans & 99.1 & P. congelans & PG02C & NA \\
\hline $\mathrm{BE} 1$ & P. syringae & 2.06 & P. syringae (rpoD) & 99.7 & P. syringae & 99.6 & P. syringae & PG02b & P1 \\
\hline BE3 & P. syringae & 2.01 & P. syringae (rpoD) & 99.8 & P. syringae & 99.6 & P. syringae & PG02b & $\mathrm{P} 2$ \\
\hline Iy3DA & P. syringae & 1.75 & P. syringae (rpoD) & 99.5 & NA & & P. syringae & PG02b & NA \\
\hline ly3EA & P. syringae & 1.98 & P. syringae (rpoD) & 99.7 & NA & & P. syringae & PG02b & NA \\
\hline ly3GB & P. syringae & 1.83 & P. syringae (rpoD) & 99.7 & NA & & P. syringae & PG02b & NA \\
\hline ly5HA & P. syringae & 2.33 & P. syringae (rpoD) & 99.7 & P. syringae & 99.2 & P. syringae & $P G 02 b$ & NA \\
\hline IyGA & P. syringae & 1.93 & P. syringae (rpoD) & 99.5 & NA & & P. syringae & PG02b & NA \\
\hline IyGC & P. syringae & 2.36 & P. syringae (rpoD) & 99.7 & NA & & P. syringae & PG02b & $\mathrm{P} 2$ \\
\hline KB49 & $\begin{array}{l}\text { P. cannabina/P. } \\
\text { syringae }\end{array}$ & $1.99 / 1.87$ & P. syringae (rpoD) & 99.7 & NA & & P. syringae & PG02b & $\mathrm{P} 2$ \\
\hline KC19 & P. syringae & 2.11 & P. syringae (rpoD) & 99.7 & NA & & P. syringae & PG02b & NA \\
\hline KC29B2 & P. syringae & 1.84 & P. syringae (rpoD) & 99.5 & NA & & P. syringae & PG02b & P2 \\
\hline KC46 & P. syringae & 2.01 & P. syringae (rpoD) & 99.5 & NA & & P. syringae & PG02b & NA \\
\hline KC54 & P. syringae & 1.94 & P. syringae (rpoD) & 99.7 & NA & & P. syringae & PG02b & P5 \\
\hline KC55 & P. syringae & 2.13 & P. syringae (rpoD) & 99.7 & NA & & P. syringae & PG02b & NA \\
\hline KC82 & P. syringae & 1.99 & P. syringae (rpoD) & 99.7 & NA & & P. syringae & PG02b & NA \\
\hline TRR12 & P. syringae & 2.06 & P. syringae (rpoD) & 99.8 & P. syringae & 99.6 & P. syringae & PG02b & $\mathrm{P} 2$ \\
\hline TRR15 & P. syringae & 2.15 & P. syringae (rpoD) & 99.9 & NA & & P. syringae & PG02b & $\mathrm{P} 2$ \\
\hline TRR9 & P. syringae & 2.02 & P. syringae (rpoD) & 99.8 & P. syringae & 99.6 & P. syringae & PG02b & $\mathrm{P} 2$ \\
\hline MTR3B & P. congelans & 2.12 & P. congelans(rpoD) & 98.2 & NA & & P. congelans & PG02C & P7 \\
\hline E10AA & P. syringae & 1.92 & P. syringae (rpoD) & 99.7 & NA & & P. syringae & PG02b & P4 \\
\hline E10CA & P. syringae & 2.42 & P. syringae (rpoD) & 99.8 & NA & & P. syringae & PG02b & $\mathrm{P} 2$ \\
\hline E10CB2 & P. syringae & 2.45 & P. syringae (rpoD) & 99.7 & P. syringae & 99.2 & P. syringae & PG02b & $\mathrm{P} 2$ \\
\hline E11 & P. syringae & 2.19 & P. syringae (rpoD) & 99.5 & P. syringae & 99.5 & P. syringae & PG02b & NA \\
\hline E12A & P. syringae & 2.17 & P. syringae (rpoD) & 99.7 & P. syringae & 99.6 & P. syringae & PG02b & NA \\
\hline E91 & P. syringae & 2.21 & P. syringae(rpoD) & 99.5 & NA & & P. syringae & PG02b & P3 \\
\hline E93A & P. syringae & 2.46 & P. syringae(rpoD) & 97.9 & NA & & P. syringae & PG02b & P6 \\
\hline E9A & P. syringae & 2.43 & P. syringae(rpoD) & 99.7 & NA & & P. syringae & PG02b & NA \\
\hline EL1A & P. syringae & 2.11 & P. syringae(rpoD) & 99.4 & P. syringae & 99.1 & P. syringae & PG02b & NA \\
\hline EL2 & P. syringae & 1.97 & P. syringae(rpoD) & 99.5 & P. syringae & 99.3 & P. syringae & PG02b & NA \\
\hline$M 5^{*}$ & $N A^{c}$ & NA & P. syringae(cts) & & NA & & P. syringae & PG02b & P8 \\
\hline M29* & NA & NA & NA & & NA & & P. syringae & PG02b & P8 \\
\hline$M 30^{*}$ & NA & NA & NA & & NA & & P. syringae & PG02b & P8 \\
\hline M32* & NA & NA & NA & & NA & & P. syringae & PG02b & P8 \\
\hline$M 47^{*}$ & NA & NA & P. syringae(cts) & & NA & & P. syringae & PG02b & P8 \\
\hline $\mathrm{V} 2 \mathrm{~A} 2 \mathrm{~F} 14^{*}$ & NA & NA & P. cerasi (cts) & & NA & NA & P. cerasi & PG02a & NA \\
\hline $\mathrm{V} 2 \mathrm{~A} 2 \mathrm{~F} 15^{*}$ & NA & NA & P. cerasi (cts) & & NA & & P. cerasi & PG02a & NA \\
\hline $\mathrm{V} 2 \mathrm{~A} 2 \mathrm{~F} 27^{*}$ & NA & NA & P. cerasi(cts) & & NA & & P.cerasi & PG02a & NA \\
\hline $\mathrm{V} 2 \mathrm{~A} 2 \mathrm{~F} 45^{*}$ & NA & NA & P. cerasi(cts) & & NA & & P.cerasi & PG02a & NA \\
\hline $\mathrm{V} 2 \mathrm{~A} 2 \mathrm{~F} 52^{*}$ & NA & NA & P. cerasi(cts) & & NA & & P.cerasi & PG02a & NA \\
\hline V2A2F79* & NA & NA & P. cerasi (cts) & & NA & NA & P. cerasi & PG02a & NA \\
\hline
\end{tabular}

a Strainwith * werelostduringthestudy and were no longeravailable to do alltests

b Biotyper-indoor DB

c NA, Not Analysed

d Score value between 2.0 and 2.3 indicates a secure identification at the genus level, but not at the species level; a value equal orhigher than 2.3 indicates a secure 
Table 2 (continued)

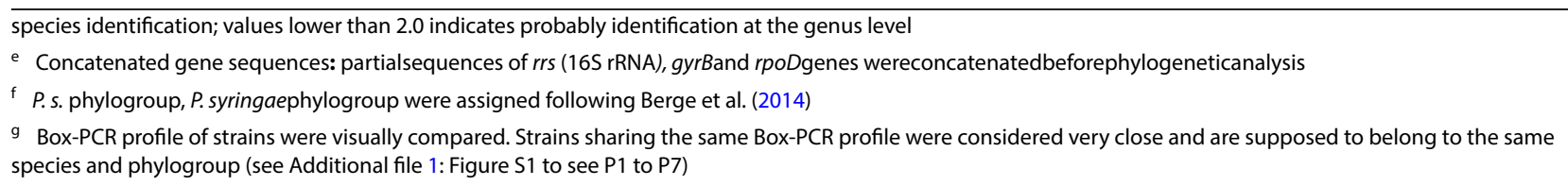

a species of the $P$. fluorescens subgroup of that lineage (Additional file 1: Table S2), and to $P$. moraviensis (10 strains from 4 different orchards), a species of the $P$. koreensis subgroup previously isolated and tested pathogenic on citrus in Iran (Beiki et al. 2016). One strain was affiliated to the P. orizyhabitans species, a Pseudomonas lineage distant of the other Pseudomonas. These species were non-pathogenic on cantaloupe (one strain per species tested) and citrus (one P. moraviensis strain tested) (Additional file 1: Table S2). As expected, the 30 oxidase negative strains were affiliated to $P$. syringae (PG02b) $(28$ strains) and P. congelans (PG02c) (2 strains) (Tables 2 and Additional file 1: S1). These two species are included in the $P$. syringae group of bacteria (Gomila et al. 2017).

Phylogenetic analyses were performed to confirm identification and to know how closely related the strains were. Analysis of the partial rpoD gene sequences of all 43 strains was consistent with the chemotaxonomic analysis results. A phylogenetic tree of these sequences including 203 Pseudomonas type strains sequences from an in-house database was constructed. It confirmed the MALDI-TOF MS identification and illustrated the strain positions in the different Pseudomonas lineages (Fig. 3). The 30 strains affiliated with the $P$. syringae group showed high percentages of identity with $P$. syringae (PG02b) and $P$. congelans (PG02c) type strains as expected (Table 2). Some representative strains of the $P$. syringae group were selected to refine the rpoD analysis by doing a multilocus sequence analysis (MLSA) of concatenated sequences of the housekeeping genes $r p o D, g y r B$ and $16 \mathrm{~S}$ rRNA as depicted in Table 2. The topology of the tree obtained (Fig. 4) was similar to that of the rpoD gene and identification of strains was definitely confirmed (Table 2). PG02b strains exhibited different haplotypes of concatenated sequences (Fig. 4) showing they were not clonal. This was confirmed by the various BOX- PCR profiles obtained for some strains (Additional file 1: Fig. S2 and Table 2).

Some enzymatic activities were tested on the 30 strains from the $P$. syringae group and were quite homogeneous whether for P. syringae (PG02b) or P. congelans (PG02c) strains (Additional file 1: Table S3). By contrast, antibiotic resistance patterns were more variable. Among the 14 strains tested, 11 were resistant at least to one antibiotic family (Additional file 1: Table S4). Nine and 6 strains were resistant to aztreonam (ATM) and gentamicin (GM) respectively, and 4 strains were resistant to both of them. Strains of $P$. congelans (PG02c) showed larger patterns of resistance than those of $P$. syringae strains. Moreover, $P$. congelans MTR3B appeared multi drug resistant (MDR3) to ATM, GM and imipenem (IMP) (Additional file 1: Table S4). Our study led to the isolation of diverse strains of the $P$. syringae group of bacteria from symptomatic citrus trees. In order to know which strains could be involved in the citrus disease in Tunisia, their pathogenicity was tested.

\section{Pathogenicity tests}

A selection of 37 representative strains (30 P. syringae (PG02b), 6 P. cerasi (PG02a) and 1 P. congelans (PG02c)) was included in these tests (Table 3 ). All the $P$. syringae (PG02b) strains injected in lemon fruits produced clear brown spots on the surface with diameters from 1.3 to $4.1 \mathrm{~cm}$ (Fig. 5 and Table 3). In the tests without injection, they produced necrosis lesion areas on fruits or leaves but were smaller in diameter $(0.2$ to $2.5 \mathrm{~cm})$ and 3 strains were negative (Table 3 ).

Agressivity of strains was quantified on cantaloupe plantlets. All 30 P. syringae (PG02b) strains but one (lyGC) exhibited quite high agressivity compared to the control strain CC94 known to be aggressive on this plant (Morris et al. 2000). All P. syringae (PG02b) strains triggered hypersensitive response on tobacco, and produced syringomycine-like toxins. These traits could be involved in the pathogenicity on citrus. Moreover they tested positive for ice nucleative activity at relatively warm temperatures $\left(-2.6\right.$ to $\left.-1.2{ }^{\circ} \mathrm{C}\right)$ which could increase the pathogeny, in the case of late frost. By contrast, the strain $P$. congelans (PG02c) BE12A produced negligible necrosis in injected lemon fruit $(0,9 \mathrm{~cm})$ and showed no effect when sprayed on the lemon fruit surface or infiltrated in lemon leaves (Table 3). It could be considered as non-pathogenic on citrus. Test HR on tobacco was not clearly positive and it produced a very small amount of syringomycin-like toxins. However, it was aggressive on cantaloupe and active for ice nucleation at $-1.5^{\circ} \mathrm{C}$.

The 3 P. cerasi (PG02a) strains tested on citrus fruit after injection produced clear necroses but smaller than those produced by P. syringae (PG02b) (Table 3). Two of these 3 strains were aggressive on cantaloupe, the last and two other strains being non-pathogenic on this plant. All the six strains of P. cerasi (PG02a) tested 


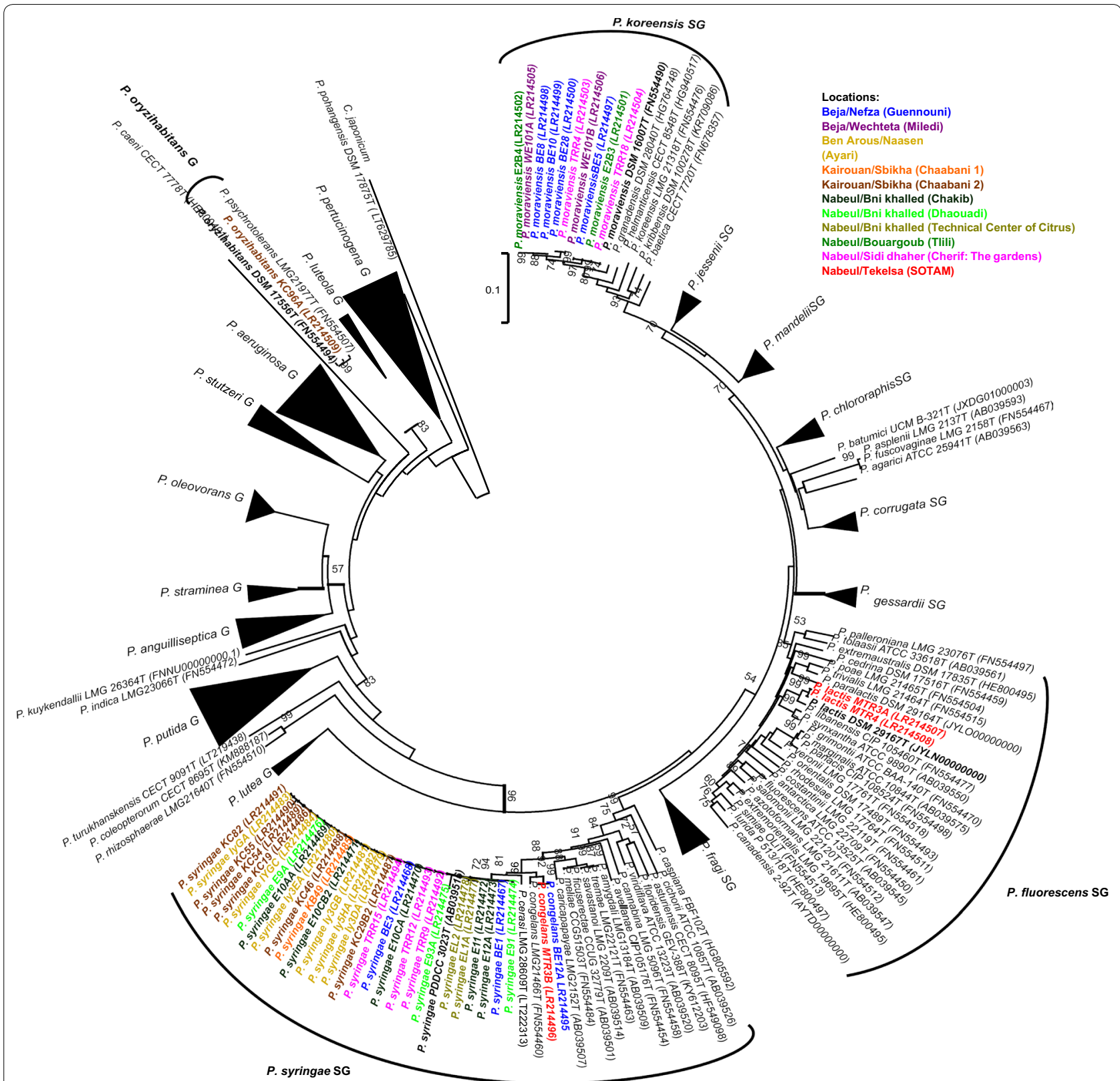

Fig.3 Phylogenetic tree of isolated strains and 203 Pseudomonas species type strains, based on the partial rpoD sequence analysis. Distance matrices were calculated by the Jukes-Cantor method (Jukes and Cantor 1969). Dendrograms were generated by the neighbour-joining method. The Cellvibrio japonicus Ueda107 rpoD sequence was used as the outgroup. The bar indicates sequence divergence. Percentage bootstrap values of more than 50\% (from 1000 replicates) are indicated at the nodes. GenBank accession numbers are given in parentheses. Colors indicate the sampling locations

on tobacco were negative and only one of them clearly produced syringomycin-like toxin. This last strain was not aggressive on cantaloupe. The pathogenicity of this group of bacteria was variable and strain dependent.

\section{Comparison of isolated strains with other P. syringae} strains isolated on symptomatic citrus from other locations The phylogenetic position of our P. syringae strains (30 strains) was compared with those isolated on citrus in 


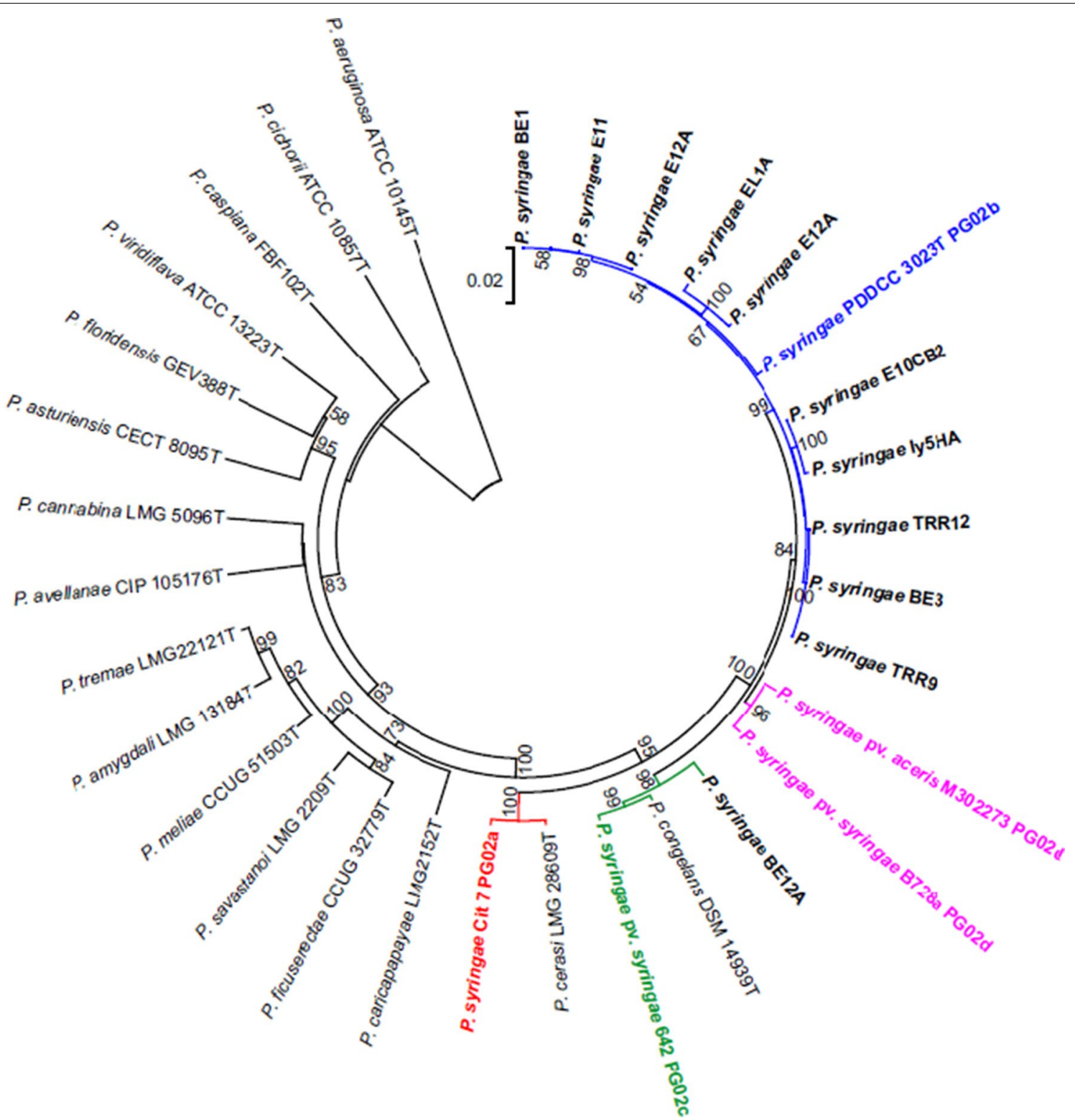

Fig.4 Phylogenetic tree of representative strains of the P. syringae group isolated in this study from citrus plants with symptoms. Concatenated $16 \mathrm{~S}$ rRNA, gyrB and $r p o D$ gene partial sequences were used and reference strains of the $P$. syringae phylogenetic group were included in the analysis. Distance matrices were calculated by the Jukes-Cantor method (Jukes and Cantor 1969). The tree was generated by the neighbour-joining method. P. aeruginosa ATCC $10145^{\top}$ was used as the outgroup. The bar indicates sequence divergence. Percentage bootstrap values of more than $50 \%$ (from 1000 replicates) are indicated at the nodes

Montenegro (12 IZB strains) and Iran (73 FBF strains) using rpoD gene sequences (Additional file 1: Fig S3). As expected, most strains were clustered with $P$. syringae (PG02b) and P. cerasi (PG02a) reference strains. By contrast only the two P. congelans (PG02c) of our study were included in the cluster with reference strains of this species. It is worth mentioning this, because no isolation of $P$. congelans (PG02c) has been reported in the previous investigations. The P. syringae (PG02b) cluster was very homogeneous, with most sequence similarities $>99.5 \%$ (Additional file 1: Table S5). In this group, two strains from Iran (FBF27 \& 47) had the same rpoD sequence as the type strain. A group of 24 strains shared the same rpoD sequence having $99.8 \%$ similarity with the type strain: all the 12 IZB strains from Serbia, two strains from Iran (FBF111 \& 138) and 10 strains from our study (BE1, 3, E10CA, E11 and 12A, EL1A, 2, TRR12, 15 and 19). Finally, remaining 


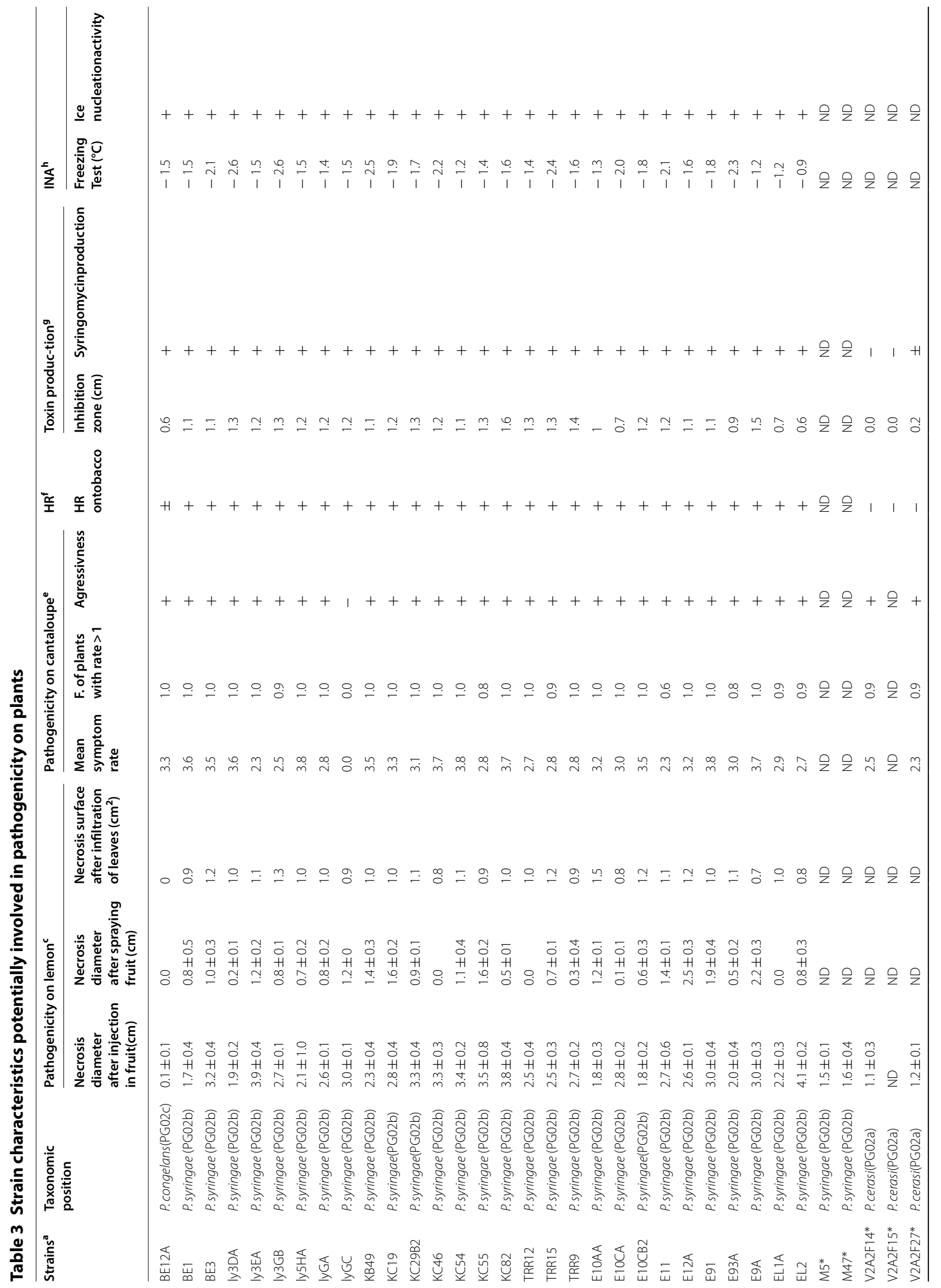




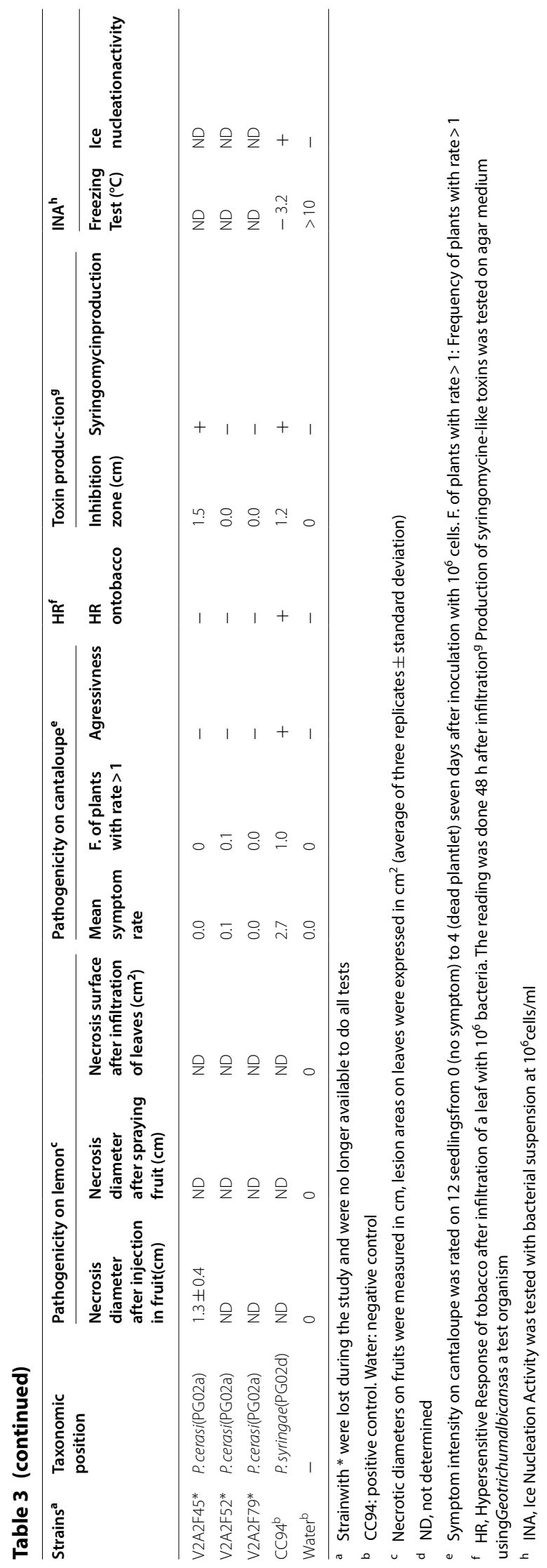



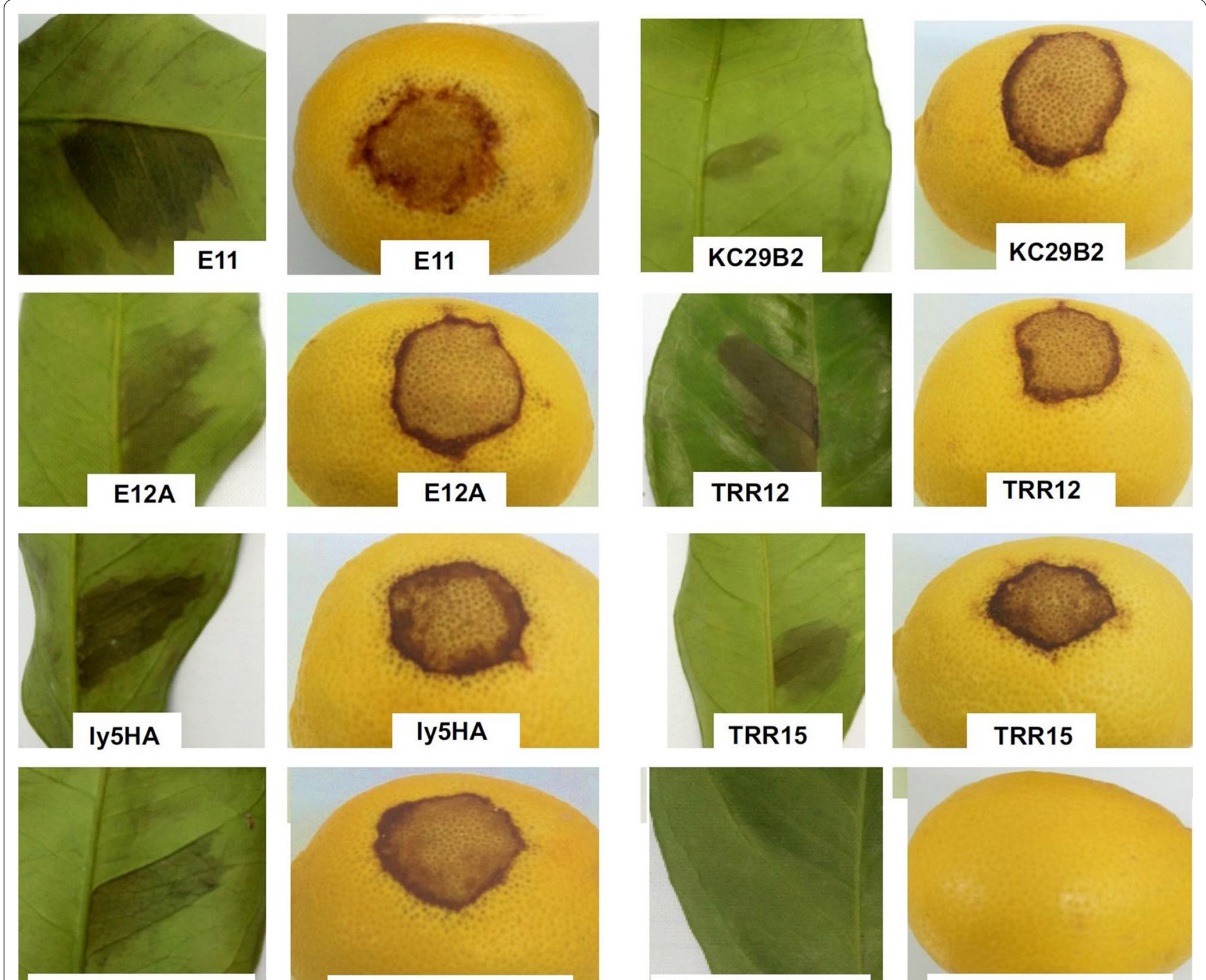

Positive control
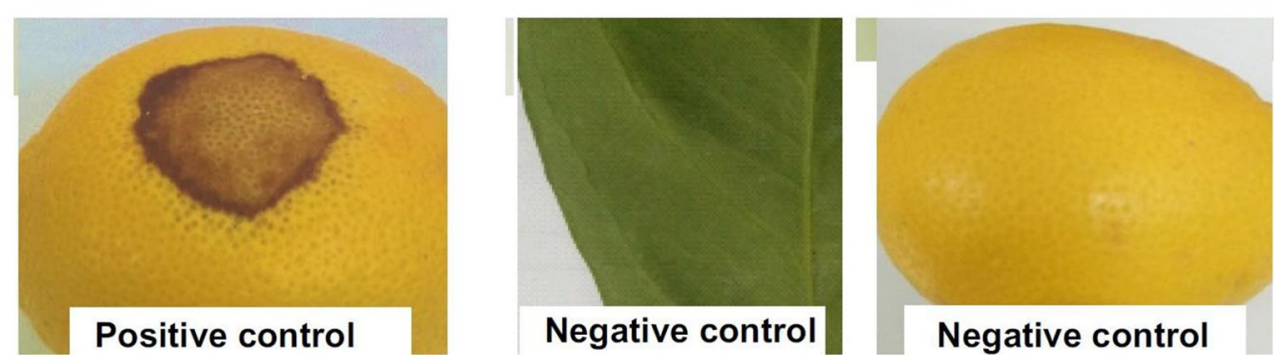

Fig.5 Detail of necrotic spots on leaves and fruits of Citrus limon cv. 'Eurêka' induced by artificial inoculation with P. syringae pv. syringae. Black pit on fruits 5 days after inoculation and blast on leaves, $24 \mathrm{~h}$ later as compared with negative control (treated with sterile distilled water)

18 P. syringae (PG02b) strains from our study and two strains from Iran (FBF46 \& 63) exhibited high sequence similarity (99.5\%) with the P. syringae type strain with this percentage being a bit lower for strains KC46 (99.3\%) and E93A (97.9\%) (Additional file 1: Table S5).

\section{Discussion}

The increase in economic losses associated with citrus blast and black pit drew our attention to the problem a few years ago, leading to a thorough investigation of the causative agent. There are several aspects to discuss based on the obtained results.

\section{Spreading of the disease in the center of Tunisia} and on various citrus cultivars

The sampling on citrus was performed over two successive seasons during two years to cover all citrus growing regions. In Tunisia, northern citrus-growing regions are known to be particularly affected by the disease. The Cap Bon area including Nabeul governate is the main producing region of citrus and the majority of orchards in this country (24) were selected. Other producing areas selected were Beja, Ben Arous, Bizerte and Jendouba governates situated in the north of Tunisia and the Kairouan governate situated in the south compared to the other places. The orchards were chosen arbitrarily. It may explain the fact of not falling 
systematically on orchards with lot of symptomatic trees. The low incidence of disease measured did not mean the absence of the disease in the area. Except the Jendouba governate where no symptom was noted, in all other governates it was possible to find symptoms including Kairouan.

In a previous work during the 2012-2015 seasons, Abdellatif et al. (2017) found symptomatic trees in orchards situated in Nabeul, Beja, Ben Arous and Bizerte governates whereas they did not find symptoms in the Kairouan governate. They considered at this time the region of Kairouan still free of the disease because it is located in the northern desert of Tunisia. The climate of this region is characterized by low humidity and high temperature compared to other regions which could explain the healthy situation of citrus orchards (Abdellatif et al. 2017). From the present work, it is clear that the disease has now spread to the Kairouan governate, at least in the Sbikha region, despite these supposed unfavourable climatic conditions (Additional file 1: Table S1). It shows the pressure of the disease is sufficiently high to contaminate a region with an unfavorable climate.

During sampling campaigns, symptoms were observed mainly on fruits, especially in spring when the delay in the harvest period coincides with higher temperature and humidity, favorable environmental conditions to disease development. Abdellatif et al. (2017) found also the disease principally as black pit on fruits and sometimes as blast on twigs, on 5 various citrus cultivars. Nevertheless isolation of pathogenic strains was successful only in 10 out 24 symptomatic orchards and among the 45 pathogenic Pseudomonas sp. isolated, 44 were from $C$. limon cv. 'Eurêka' the last being isolated from C. sinensis cv.'Washington Navel'. In the present work successful isolation was also low (positive in 10 out 37 orchards) and probably due to the low level of bacterial population or its migration in another part of the plant. The disease was confirmed on C. limon cv. 'Eurêka' and its spread to many other cultivars was also shown, taking into account all orchards, eight cultivars developed symptoms (Additional file 1: Table S1). Pathogenic Pseudomonas was isolated from 6 of them: C. limon cvs. 'Eurêka' and 'Lunari', C. reticulata cv. Hernandina' and 'Cassar' and C. sinensis cvs. 'Maltaise' and 'Valencia Late'. It shows that the disease spread geographically as well as to more and more citrus cultivars.

\section{Diversity of strains from the $P$. syringae group of bacteria}

In the present study, among the 820 strains isolated on $\mathrm{KB}, 41$ strains $(5 \%)$ were identified to the $P$. syringae group of bacteria. They all belong to the PG02 phylogroup following the current $P$. syringae classification proposed by Berge et al. (2014). The P. syringae PG02 phylogroup is ubiquitous, it contains many pathogenic strains isolated from a wide range of plants and could be isolated from very diverse subtsrates (wild plant, river, snow, rain ...). It contains mostly very aggressive strains when tested on cantaloupe seedlings, frequent ice nucleation active bacteria and strains able to produce a syringomycin- like toxin (Berge et al. 2014). P. syringae PG02 strains of this study were identified to three species. As shown previously, the most prevalent on citrus was the $P$. syringae $\mathrm{PG} 02 \mathrm{~b}$ that includes the $P$. syringae $\mathrm{pv}$. syringae van Hall 1902, PDDCC $3023^{\mathrm{T}}$ type strain. The majority of isolated strains in this work ( $75 \%, 33$ strains) were affiliated with this species. They were isolated in many places and cultivars. They were found on 5 citrus cultivars in 8 orchards located in 4 governates. This study confirmed that these strains play a major role in the disease on citrus in Tunisia as shown previously (Abdellatif et al. 2017).

The intragroup diversity of our $P$. syringae PG02b strains was explored using BOX-PCR fingerprinting and it revealed that these strains were diverse, exhibiting at least 7 different fingerprints (Table 2). However, one clonal strain (P2 BOX-profile) was more frequent and it could represent a dominant epidemic strain widespread in Tunisia. A quantitative approach during isolation could help to know better the real prevalence of each type of strain and their involvement in the diseases. In addition to the expected P. syringae (PG02b) and for the first time in Tunisia, 6 strains from the P. syringae PG02, identified as $P$. cerasi (P. syringae PG02a) were found. They represented $14 \%$ of isolated strains and were found in only one orchard classified in class1 of sanitary state, on C. sinensis 'Maltaise' independently of the PG02b strains. This work demonstrated that these strains could produce characteristic symptoms of the diseases in Tunisia, likely with a lower level of aggressiveness than $P$. syringae (PG02b). For some of them they were very aggressive on cantaloupe and could be involved in outbreaks of such crops if grown near citrus orchards (Table 3 ). The species $P$. cerasi is closely related to $P$. syringae (PG02b) and was first described with strains isolated from diseased tissue of cherry trees in Poland (Kaluzna et al. 2016). However, this species potentially included strains of the PG02a phylogroup, isolated from wild plant (Hirano and Upper 1990), rain and irrigation basin (Berge et al. 2014).

The presence of this species in citrus diseases and its spreading in other regions and cultivars need to be studied in the future in Tunisia in order to better understand its role in the disease. The last species of the $P$. syringae PG02 was $P$. congelans (P. syringae PG02c) with $4 \%$ of isolated strains (2 strains) from 2 orchards located in 2 governates. P. congelans (PG02c) strains were isolated from C. reticulata 'Hernandina' and C. sinensis 'Valencia Late', presenting the gummosis of the branches and 
the black pit respectively. One of these two strains was tested non- pathogenic on citrus, but was very aggressive on cantaloupe and positive in the HR test. The strains were present on trees of sanitary status classified as class 2 and 3. P. congelans was first described as nonpathogenic from the phyllosphere of grasses (Behrendt et al. 2003) and actually potentially included strains of the PG02c phylogroup. These strains have been described previously as dominated by pathogenic strains isolated sometimes from plants and frequently from environmental substrates linked to the water cycle (Berge et al. 2014) or having a biocontrol activity against fire blight (Mikicińskiet al. 2020). At the opposite of the other strains from the P. syringae phylogroup PG02 having the canonical Type Three Secretion System (T3SS) used to secrete proteins that help the bacteria infect plant cells, PG02c strains have an atypical T3SS similar to S-PAI of $P$. viridiflava (Clarke et al. 2010). However, these strains can be pathogenic (Demba Diallo et al. 2012). Both P. congelans (PG02c) strains were resistant to streptomycin, the main antibiotic currently in use for plant disease control as well as to chloramphenicol, amoxcillin, tobramycin and carbenicillin. One of these strains was classified as a Multi Drug Resistant organism in our tests (Additional file 1: Table S3). It seems that this group of bacteria is not directly involved in the citrus diseases: however, it could play a role for example during late frost, through its ice nucleation activity tested at $-1.5{ }^{\circ} \mathrm{C}$. Thus, the pathogenic population could more easily colonize the frozen tissues damaged by ice crystals produced by $P$. congelans.

Koch's postulates were validated on citrus for more than one epidemic strain of $P$. syringae. It is clear from this work that bacteria from at least two species, $P$. syringae (PG02b) and P. cerasi (PG02a) were able to induce symptoms on citrus and may be involved in the diseases. Moreover, the isolated strains were diverse and more than 7 BOX-profiles were found showing the nonclonality of the pathogenic strains. The citrus-P. syringae pathosystem is complex as shown previously on Prunus species. Ruinelli et al. (2019) found that a large number of various $P$. syringae strains are pathogenic on the tested hosts (cherry, peach and almond). Similarly Parisi et al. (2019), isolated four phylogroups (PG01, 02, 03 and 07) able to induce canker on apricot. Ruinelli et al. (2019) suggest the diversity of strains pathogenic on Prunus is probably due to independent evolution of individual strains, not necessarily related to virulence.

\section{Diverse other Pseudomonas species isolated from symptomatic trees}

Beyond tracking the $P$. syringae group of bacteria, this study aimed to prospect for the population diversity of some other Pseudomonas species associated with the disease, following the work of Beiki et al. (2016). They showed that a very diverse population of Pseudomonas strains was associated with citrus blast in Iran: some from the $P$. syringae group of bacteria as expected but also and for the first time, other species such as $P$. lurida, P. monteilli, $P$. moraviensis, $P$. orientalis, $P$. simiae, and the new species $P$. caspiana (Busquets et al. 2017). To reach this goal, 6 strains of $P$. moraviensis were isolated coexisting with $P$. syringae strains from $C$. sinensis cv. 'Valencia Late' and $C$. limon cv. 'Lunari' fruits. The other $4 P$. moraviensis strains were isolated independently from $P$. syringae on C. limon cv. 'Eurêka'. All trees were classified in the class 3 sanitary state (Additional file 1: Table S1). Only one strain was tested for pathogeny and was negative. P. moraviensis (Tvrzovà et al. 2006) is an ubiquist species with high metabolic versatility and bioremediation potential (Miller et al. 2016). It is also considered as a PGPR (Plant Growth-Promoting Rhizobacteria) (Hassan et al. 2016). Two other Pseudomonas species, P. lactis and P. oryzihabitans were isolated respectively from C. reticulata cv'Hernandina' and C. sinensis cv. 'Valencia Late' coexisting with some $P$. syringae strains on trees classified as class 2 sanitary status (Additional file 1: Table S1). In citrus orchards, these three Pseudomonas species not closely related to the $P$. syringae group of bacteria (Mulet et al. 2010) should be considered as opportunistic bacteria associated with symptoms (Beiki et al. 2016) and their involvement in the disease needs to be explored. In the same survey as this study, two new species pathogenic on citrus $P$. kairouanensis and $P$. nabeulensis formerly described elsewhere (Oueslati et al. 2019), were found respectively in orchards surveyed in Kairouan and Nabeul governates (Additional file 1: Table S1). These new citrus pathogens may be involved in the disease as well as the P. syringae group of bacteria.

\section{Diversity of $P$. syringae in the Mediterranean area and Caspian regions}

It has been demonstrated previously in different countries that citrus blast and citrus black pit are caused primarily by homogenous populations of $P$. syringae (PG02b) close to the type strain of P. syringae pv. syringae PDDCC $3023^{\mathrm{T}}$ like in Turkey (Mirik et al. 2005). Abdellatif et al. (2017) suggested the homogeneity of $P$. syringae strains isolated in Tunisia on citrus might have originated from a single inoculum source linked to commercial exchanges following Ivanović et al. (2017) in Montenegro. The latter demonstrated that the single strain of $P$. syringae PG02b, causing citrus blast on mandarin in this country, originated from planting material. In Iran, Beiki et al. (2016) isolated some $P$. syringae (PG02b) strains close to the type strain PDDCC $3023^{\mathrm{T}}$ together with very 
diverse pathogenic Pseudomonas species involved in the disease.

The phylogenetic position of our strains was compared with those from Iran and from Serbia using rpoD gene sequences. It was not possible to include strains previously isolated in Tunisia, because they were identified using 16S rRNA gene sequences (Abdellatif et al. 2017) unsuitable to discriminate between Pseudomonas species, neither phylogroups of the $P$. syringae group of bacteria (Yamamoto et al. 2000; Parkinson et al. 2011). Based on rpoD phylogeny, it is clear that a group of closely related strains from $P$. syringae (PG02b) is involved in citrus diseases in the three different countries. These strains are not clonal, as far as they represented various rpoD haplotypes (Additional file 1: Fig. S3), but probably shared the main phenotypic traits linked to pathogeny. The wide dispersion of this group of $P$. syringae (PG02b) in the Mediterranean Basin and Caspian region and the high similarities in the $r p o D$ nucleotide sequences suggest they are a group of strains well-adapted (high fitness) to citrus. Some strains affiliated with the PG02d clade were isolated in Iran, not all are pathogenic on citrus (Beiki et al. 2016). This clade is very closely related to the P. syringae PG02b and was not found in Tunisian orchards. Another large group of related strains involved in the disease in two of the three countries appears clearly in Additional file 1: Fig. S3 as being the P. cerasi (PG02a) species. These strains are not clonal and may be more variable among phenotypes (Additional file 1: Table S4). This group represents an emerging pathogen in Tunisia, where it was found in only one orchard. Monitoring their spreading in other regions and cultivars in the future could help to see their fitness in this context. Exploring their phenotypic and genotypic structures and their pathogenic characteristics could help to better understand their role in the disease.

Finally, for the first time a third group of strains belonging to $P$. congelans (PG02c) was isolated on citrus. Although not pathogenic on citrus, they can be very aggressive on cantaloupe, and active for ice nucleation at high temperature $\left(-1.5^{\circ} \mathrm{C}\right)$. It would be interesting to explore further their role in the citrus diseases. This species had not been described on citrus so far, because it does not produce symptoms on plant tissues when inoculated in pure culture. This $P$. congelans (PG02c) bacteria could be tested in co-inoculation experiments with a $P$. syringae pathogenic strain to see the impact of this bacterium on symptom development particularly if doing a cold shock.

In conclusion, this study demonstrated that citrus diseases have progressed in Tunisia. The governate of Kairouan is now affected by the disease despite their non-favorable climate. The pathogenic strain affiliated to P. syringae (PG02b) previously described on citrus were frequently isolated in Tunisian orchards and spread in Tunisia in all regions and on many cultivars. This species is widely distributed in producing countries and may represent an epidemic group of strains disseminated through plant material or commercial exchanges. Moreover, our work showed that this pathogen is not unique. One more pathogenic species of the P. syringae group, P. cerasi (PG02a) and two new pathogenic species of Pseudomonas, P. kairouanensis and $P$. nabeulensis are involved in the diseases in Tunisia (Oueslati et al. 2019). P. cerasi (PG02a) is emergent in Tunisia and requires special attention as it was frequently isolated previously in Iran and was aggressive on citrus (Beiki et al. 2016). It could disseminate and cause damages and economic losses. In the same way, the two new described pathogenic species were isolated only in one orchard and little information is available on them and the danger they represent. P. cerasi (PG02a), P. kairouanensis and P. nabeulensis, should be included in future surveys of pathogens involved in citrus blast and black pit in Tunisia as well as in other countries where these diseases are present. It will be important to include these species in the diagnostic scheme, identification of reservoirs (Mougou and Boughalleb-M'hamdi 2016) and the biocontrol research mainly focused on P. syringae (PG02b) (Mougou and Boughalleb-M'hamdi 2016).

To be effective and to have an adequate biocontrol measures using antagonistic bacteria or bacteriophages (Braun-Kiewnick et al. 2000; Pinheiro et al. 2019), it is then necessary to know very well the pathogenic populations responsible for the disease. For that, isolation of pathogenic bacteria using an approach without a priori is particularly efficient when ubiquitous diverse bacteria like those of the $P$. syringae group of bacteria are involved. In addition to their ability to disseminate between cultivars and sites, Vasebi et al. (2019) have shown that strains of $P$. syringae pv. syringae isolated from diseased apricot trees can adapt to other alternative hosts such as citrus and cause symptoms. The polyphagous nature of these bacteria allows it to pass from one crop to another and requires the use of an integrated management targeting several cultures in a region. Our results from the phenotypic and genomic variability of $P$. syringae can be used for studies on varietal susceptibility, the determination of the host range and the development of management and control strategies for this topical bacterial disease. Finally, the presence of ubiquitous species in symptomatic tissue like $P$. congelans, $P$. moraviensis, $P$. lactis and $P$. oryzyhabitans and some others open new perspectives of studies on their role in the development of the disease and their interactions with pathogens. 
This study reveals that this disease is more complex than previously thought and pathogenic bacteria involved are diverse and complex. Disease on trees can develop during more than only one season and different part of the plant and various pathogens can succeed each other, or cohabited and cooperate. The economic context and the pressure of the market on the citrus growers led to a longer and longer delay of the harvest that favors the dissemination and growth of bacterial populations and the development of symptoms. In that context, to limit the effect of the diseases on yield, it will be very important to determine the role of each pathogen during the season and their interactions with each other and with the plant microbiota.

\section{Supplementary information}

Supplementary information accompanies this paper at https://doi. org/10.1186/s13568-020-01134-z.

Additional file 1: Table S1. Localization and characteristics of the Tunisian orchards surveyed for blast and black pit disease in 2015, 2016 and 2017. Table S2. Other Pseudomonas strains characteristics isolated from symptomatic samples. Table S3. Detection of enzymatic activity of $P$. syringae and $P$. congelans strains of this study, using API ZYM system. Table S4. Resistance antibiotic patterns of the $P$. syringae and $P$. congelans strains used in this study. Table S5. Matrix of pairwise genetic similarity of rpoD gene sequences of strains of this study, strains from symptomatic citrus in Iran (FBF strains) and in Serbia (IZB strains). Fig. S1. Phylogenetic tree built with Neighbor joining method based on cts partial sequences of $P$. syringae strains isolated from Tunisian citrus orchards. Fig. S2. BOX fingerprints of representative strains of the $P$. syringae group isolated from citrus in symptomatic Tunisian orchards from different regions. Fig. S3. Phylogenetic tree based on the $r p o D$ gene sequences of $P$. syringae strains of this study, together with other strains of P. syringae from Tunisia, (Abdellatif et al. 2017), Montenegro (Ivanović et al. 2017) and Iran (Beiki et al. 2016). Distance matrices were calculated by the Jukes-Cantor method (Jukes and Cantor 1969). Dendrograms were generated by the neighbourjoining method. P. aeruginosa ATCC 10145 T was used as the outgroup. The bar indicates sequence divergence. Percentage bootstrap values of more than 50\% (from 1000 replicates) are indicated at the nodes. GenBank accession numbers are given in parentheses.

\section{Acknowledgements}

Authors want to thank Caroline Guilbaud, from INRAE, Plant Pathology Research Unit Monfavet (France) for her help in performing BOX-PCR fingerprint and cts phylogeny of strains and Mr Abdelfetah SAID from the Technica Center of Citrus (CTA) in Tunisia for his valuable technical support on this project.

\section{Authors' contributions}

OM carried out the experiment and wrote the manuscript with support from GE, BO, L, SN and MM. SN and HM supervised the Project. MM, GE and BO analyzed data. MM and CC performed the experiments. ZM and HM contributed to sampling. All authors read and approved the manuscript.

\section{Funding}

This study was funded by the Spanish MINECO (CGL2015-70925), co-founded by the European Regional Development Fund/European Social Fund "Investing in your future" (FEDER). This work was also supported by funds from the PRF Project (PRF14CTABIOTEC02) and by the Ministry of Higher Education and Scientific Research of Tunisia (LR16ES05).
Ethical approval and consent to participate

This article does not contain any studies with human participants or animals performed by any of the authors.

\section{Competing interest}

All authors declare that they have no conflict of interest.

\section{Author details}

${ }^{1}$ Laboratoire de Mycologie, Pathologies et Biomarqueurs (LR16ES05), Département de Biologie, Université de Tunis-El Manar, 2092 Tunis, Tunisie. ${ }^{2}$ Microbiologia, Departament de Biologia, Edifici Guillem Colom, Universitat de Les Illes Balears, Campus UIB, 07122 Palma de Mallorca, Spain. ${ }^{3}$ INRAE, Pathologie Végétale, 84140 Monfavet, France. ${ }^{4}$ Institut Mediterrani D’Estudis Avançats (IMEDEA, CSIC-UIB), Campus UIB, 07122 Palma de Mallorca, Spain. ${ }^{5}$ Laboratoire de Biotechnologie Appliquée à l'Agriculture, INRA Tunisia, Université de Carthage, 2094 Ariana, Tunisia.

Received: 18 October 2020 Accepted: 21 October 2020 Published online: 01 November 2020

\section{References}

Abdellatif E, Kaluzna M, Helali F, Cherif M, Janse JD, Rhouma A (2015) First report of citrus bacterial blast and citrus black pit caused by Pseudomonas syringae pv. syringae in Tunisia. New Dis Rep 32:35

Abdellatif E, Kałużna M, Janse JD, Sobiczewski P, Helali F, Lamichhane JR, Rhouma A (2017) Phenotypic and genetic characterization of Pseudomonas syringae strains associated with the recent citrus bacterial blast and bacterial black pit epidemics in Tunisia. Plant Pathol 66:1081-1093

Bauer AW, Kirby WMM, Sherris JC, Turck M (1966) Antibiotic susceptibility testing by a standardized single disk method. Am J Clin Pathol 45:493-496

Behrendt U, Ulrich A, Schumann P (2003) Fluorescent pseudomonads associated with the phyllosphere of grasses; Pseudomonas trivialis sp. nov., Pseudomonas poae sp. nov. and Pseudomonas congelans sp. nov. Int J Syst Evol Microbiol 53:1461-1469

Beiki F, Busquets A, Gomila M, Rahimian H, Lalucat J, Garcia-Valdes E (2016) New Pseudomonas spp. are pathogenic to Citrus. PLoS ONE 11:1-16

Berge O, Monteil CL, Bartoli C, Chandeysson C, Guilbaud C, Sands DC, Morris CE (2014) A user's guide to a data base of the diversity of Pseudomonas syringae and its application to classifying strains in this phylogenetic complex. PLoS ONE 9:e105547

Braun-Kiewnick A, Jacobsen BJ, Sands DC (2000) Biological control of Pseudomonas syringae pv. syringae, the causal agent of basal kernel blight of barley, by antagonistic Pantoea agglomerans. Phytopathology 90:368-375

Bright JJ, Claydon MA, Soufian M, Gordon DB (2002) Rapid typing of bacteria using matrix-assisted laser desorption ionisation time-of-flight mass spectrometry and pattern recognition software. J Microbiol Meth 48:127-138

Busquets A, Gomila M, Beiki F, Mulet M, Rahimian H, García-Valdés E, Lalucat J (2017) Pseudomonas caspiana sp. nov., a citrus pathogen in the Pseudomonas syringae phylogenetic group. Syst Appl Microbiol 40:266-273

Clarke CR, Cai R, Studholme DJ, Guttman D, Vinatzer BA (2010) Pseudomonas syringae strains naturally lacking the classical P. syringae hrp/hrc locus are common leaf colonizers equipped with an atypical type III secretion system. Mol Plant Microbe Interact 23:198-210

Demba Diallo M, Monteil CL, Vinatzer BA, Clarke CR, Glaux C, Guilbaud C, Desbiez C, Morris CE (2012) Pseudomonas syringae naturally lacking the canonical type III secretion system are ubiquitous in non agricultural habitats, are phylogenetically diverse and can be pathogenic. ISME J 6:1325-1335

Ewing WH (1962) Enterobacteriaceae, biochemical methods for group differentiation. Health Serv Publ 734:1-30

Ghyselinck J, Coorevits A, Van Landschoot A, Samyn E, Heylen K, De Vos P (2013) An rpoD gene sequence based evaluation of cultured Pseudomonas diversity on different growth media. Microbiology 159:2097-2108

Gilbert V, Planchon V, LegrosF MH, Bultreys A (2010) Pathogenicity and aggressiveness in populations of Pseudomonas syringae from Belgian fruit orchards. Eur J Plant Pathol 126:263-277 
Gomila M, Busquets A, Mulet M, García-Valdés E, Lalucat J (2017) Clarification of taxonomic status within the Pseudomonas syringae species group based on a phylogenomic analysis. Front Microbiol 8:2422

Gross DC, Devay JE (1977) Role of syringomycin in holcus spot of maize and systemic necrosis of cowpea caused by Pseudomonas syringae. Physiol Plant Pathol 11:1-11

Gross DC (1985) Regulation of syringomycin synthesis in Pseudomonas syringae pv. syringae and defined conditions for its production. J Appl Bacteriol 58:167-174

Gruner E, von Graevenitz A, Altwegg M (1992) The API ZYM system: a tabulated review from 1977 to date. J Microbiol Meth 16:101-118

Hassan TU, Bano A, Naz I (2016) Alleviation of heavy metals toxicity by the application of plant growth promoting rhizobacteria and effects on wheat grown in saline sodic field. Int J Phytoremediat 19:522-529

Hirano SS, Upper CD (1990) Population biology and epidemiology of Pseudomonas syringae. Annu Rev Phytopathol 28:155-177

Hirano SS, Upper CD (2000) Bacteria in the leaf ecosystem with emphasis on Pseudomonas syringae a pathogen, ice nucleus, and epiphyte. Microbiol Mol Biol R 64:624-653

lacobellis NS, Sisto A, Surico G, Evidente A, DiMaio E (1994) Pathogenicity of Pseudomonas syringae subsp. savastanoi mutants defective in phytohormone production. J Phytopathol 140:238-248

Ivanović Z, Perovic T, Popovic T, Blagojevic J, Trkulja N, Hrncic S (2017) Characterization of Pseudomonas syringae pv. syringae, causal agent of citrus blast of mandarin in montenegro. Plant Pathol J 33:21-33

Jukes TH, Cantor CR (1969) Evolution of protein molecules. In: Munro HN (ed) Mammalian protein metabolism. Academic Press, New York, pp 21-132

Kałuzna M, Willems A, Pothier JF, Ruinelli M, Sobiczewski P, Puławska J (2016) Pseudomonas cerasi sp. Nov. (non Griffin, 1911) isolated from diseased tissue of cherry. Syst Appl Microbiol 39:370-377

King EO, Ward MK, Raney DE (1954) Two simple media for the demonstration of pyocyanin and fluorescin. J Lab Clin Med 44:301-307

Koeuth T, Versalovic J, Lupski JR (1995) Differential subsequence conservation supports the mosaic nature of interspersed repetitive BOX elements in bacteria. Plant Pathol 5:408-418

Lamichhane JR, Varvaro L, Parisi L, Audergon J-M, Morris CE (2014) Disease and frost damage of woody plants caused by Pseudomonas syringae, seeing the forest for the trees. Adv Agron 126:235-295

Lamichhane JR, Messéan A, Morris CE (2015) Insights into epidemiology and control of diseases of annual plants caused by the Pseudomonas syringae species complex. J Gen Plant Pathol 81:331-350

Lelliott RA, Billing E, Hayward AC (1966) A determinative scheme for the fluorescent plant pathogenic pseudomonads. J Appl Microbiol 29:470-489

Magiorakos AP, Srinivasan A, Carey RB, Carmeli Y, Falagas ME, Giske CG, Monnet DL (2012) Multidrug-resistant, extensively drug-resistant and pandrugresistant bacteria: an international expert proposal for interim standard definitions for acquired resistance. Clin Microbiol Infec 18:268-281

Mansfield J, Genin S, Magori S, Citovsky V, Sriariyanum M, Ronald P, Dow M, Verdier V, Beer SV, Machado MA, Toth I, Salmond G, Foster GD (2012) Top 10 plant pathogenic bacteria in molecular plant pathology. Mol Plant Pathol 13:614-629

Marques ASA, Marchaison A, Gardan L, Samson R (2008) BOX-PCR-based identification of bacterial species belonging to Pseudomonas syringae-P. viridiflava group. Genet Mol Biol 31:106-115

Martin-Sanz A, De La Vega MP, Murillo J, Caminero C (2013) Strains of Pseudomonas syringae $\mathrm{pv}$. syringae from pea are phylogenitically and pathogenically diverse. Phytopathology 103:673-681

Mensi I, Jabnoun-Khiareddine H, Zarrougui NE, Zahra BH, Cesbron S, Jacques MA, Daami-Remadi M (2018) First report of tomato bacterial speck caused by Pseudomonas syringae pv. tomato in Tunisia. New Dis Rep 38:21

Mikiciński A, Puławska J, Molzhigitova A, Sobiczewsk P (2020) Bacterial species recognized for the first time for its biocontrol activity against fire blight (Erwinia amylovora). Eur J Plant Pathol 156:257-272

Miller NT, Fuller D, Couger MB, Bagazinski M, Boyne P, Devor RC, Youssef N (2016) Draft genome sequence of Pseudomonas moraviensis strain Devor implicates metabolic versatility and bioremediation potential. Genom Data 9:154-159

Mirik M, Baloglu S, Aysan Y, Cetinkaya-Yildiz R, Kusek M, Sahin F (2005) First outbreak and occurrence of citrus blast disease, caused by Pseudomonas syringae pv. syringae, on orange and mandarin trees in Turkey. Plant Pathol 54:238-238

Monteil CL, Guilbaud C, Glaux C, Lafolie F, Soubeyrand S, Morris CE (2011) Emigration of the plant pathogen Pseudomonas syringae from leaf litter contributes to its population dynamics in alpine snowpack. Environ Microbiol 14:2099-2112

Morris CE, Glaux C, Latour X, Gardan L, Samson R, Pitrat M (2000) The relationship of host range, physiology, and genotype to virulence on cantaloupe in Pseudomonas syringae from cantaloupe blight epidemics in France. Phytopathology 90:636-646

Morris CE, Kinkel LL, Xiao K, Prior P, Sands DC (2007) Surprising niche for the plant pathogen Pseudomonas syringae. Infect Genet Evol 7:84-92

Morris CE, Sands DC, Vinatzer BA, Glaux C, Guilbaud C, Buffière A, Yan S, Dominguez H, Thompson BM (2008) The life history of the plant pathogen Pseudomonas syringae is linked to the water cycle. ISME J 2:321-334

Morris CE, Sands DC, Vanneste JL, Montarry J, Oakley B, Guilbaud C, Glaux C (2010) Inferring the evolutionary history of the plant pathogen Pseudomonas syringae from its biogeography in headwaters of rivers in north America, Europe, and New Zealand. mBio 1:e00107

Morris CE, Monteil CL, Berge O (2013) The life history of Pseudomonas syringae: linking agriculture to earth system processes. Annu Rev Phytopathol 51:85-104

Morris CE, Lamichhane JR, Nikolić I, Stanković S, Moury B (2019) The overlapping continuum of host range among strains in the Pseudomonas syringae complex. Phytopathol Res 1:4

Mougou A, Boughalleb-M'Hamdi N (2016) Detection, survival, and source of inoculum of Pseudomonas syringae $\mathrm{pv}$. syringae from weeds and plant debris in relation to epidemiology of bacterial citrus blast and black pit in Tunisia. Br Microbiol Res J16:1-10

Mougou A, Boughalleb-M'Hamdi N (2018) Biocontrol of Pseudomonas syringae pv. syringae affecting citrus orchards in Tunisia by using indigenous Bacillus spp. and garlic extract. EJBPC 28:60

Mulet M, Gomila M, Gruffaz C, Meyer J, Palleroni NJ, Lalucat J, García-Valdés E (2008) Phylogenetic analysis and siderotyping as useful tools in the taxonomy of Pseudomonas stutzeri: description of a novel genomovar. Int J Syst Evol Microbiol 58:2309-2315

Mulet M, Lalucat J, García-Valdés E (2010) DNA sequence-based analysis of the Pseudomonas species. Environ Microbiol 12:1513-1530

Mulet M, Gomila M, Scotta C, Sánchez D, Lalucat J, García-Valdés E (2012) Concordance between whole-cell matrix-assisted laser-desorption/ionization time-of-flight mass spectrometry and multilocus sequence analysis approaches in species discrimination within the genus Pseudomonas. Syst Appl Microbiol 35:455-464

Mulet M, Gomila M, Ramírez A, Cardew S, Moore ERB, Lalucat J, García-Valdés E (2016) Uncommonly isolated clinical Pseudomonas: identification and phylogenetic assignation. Eur J Clin Microbiol 36:351-359

Oueslati M, Mulet M, Gomila M, Berge O, Hajlaoui MR, Lalucat J, García-Valdés E (2019) New species of pathogenic Pseudomonas isolated from citrus in Tunisia: proposal of Pseudomonas kairouanensis sp. nov. and Pseudomonas nabeulensis sp. nov. Syst Appl Microbiol 42:348-359

Parisi L, Morgaint B, Blanco-Garcia J, Guilbaud C, Chandeysson C, Bourgeay J, Moronvalle A, Brun L, Brachet M, Morris C (2019) Bacteria from four phylogroups of the Pseudomonas syringae complex can cause bacterial canker of apricot. Plant Pathol 68:1249-1258

Parkinson N, Bryant R, Bew J, Elphinstone J (2011) Rapid phylogenetic identification of members of the Pseudomonas syringae species complex using the rpoD locus. Plant Pathol 60:338-344

Pinheiro LAM, Pereira C, Frazão C, Balcão VM, Almeida A (2019) Efficiency of phage $\varphi 6$ for biocontrol of Pseudomonas syringae pv. syringae: an in vitro preliminary study. Microorganisms 7:286

Ruinelli M, Blom J, Smits THM, Pothier JF (2019) Comparative genomics and pathogenicity potential of members of the Pseudomonas syringae species complex on Prunus spp. BMC Genomics 20:172

Sánchez D, Matthijs S, Gomila M, Tricot C, Mulet M, García-Valdés E, Lalucat J (2014) rpoD gene pyrosequencing for the assessment of Pseudomonas diversity in a water sample from the woluwe river. Appl Environ Microbiol 80:4738-4744

Sánchez D, Mulet M, Rodríguez AC, David Z, Lalucat J, García-Valdés E (2014) Pseudomonas aestusnigri sp. nov., isolated from crude oil-contaminated intertidal sand samples after the Prestige oil spill. Syst Appl Microbiol 37:89-94 
Sarkar SF, Guttman DS (2004) Evolution of the core genome of Pseudomonas syringae, a highly clonal, endemic plant pathogen. Appl Environ Microbiol 70:1999-2012

Stopelli E, Conen F, Zimmermann L, Alewell C, Morris CE (2014) Freezing nucleation apparatus puts new slant on study of biological ice nucleators in precipitation. Atmos Meas Tech 7:129-134

Tamura K, Peterson D, Peterson N, Stecher G, Nei M, Kumar S (2011) MEGA5: molecular evolutionary genetics analysis using maximum likelihood, evolutionary distance, and maximum parsimony methods. Mol Biol Evol 28:2731-2739

Tvrzovà L, Schumann P, Sproer C, Sedlacek I, Pacova Z, Sedo O, Lang E (2006) Pseudomonas moraviensis sp. nov. and Pseudomonas vranovensis sp. nov., soil bacteria isolated on nitroaromatic compounds, and emended description of Pseudomonas asplenii. Int JSyst Evol Microbiol $56: 2657-2663$
Vasebi Y, Khakvar R, Faghihi MM, Vinatzer A (2019) Genomic and pathogenic properties of Pseudomonas syringae pv. syringae strains isolated from apricot in East Azerbaijan province. Biocatal Agric Biotechnol 19:101167

Xin XF, Kvitko B, He SY (2018) Pseudomonas syringae: what it takes to be a pathogen. Nat Rev Microbiol 16:316-328

Yamamoto S, Harayama S, Arnold DL, Jackson RW, Kasai H, Vivian A (2000) Phylogeny of the genus Pseudomonas: intrageneric structure reconstructed from the nucleotide sequences of gyrB and rpoD genes. Microbiology 146:2385-2423

\section{Publisher's Note}

Springer Nature remains neutral with regard to jurisdictional claims in published maps and institutional affiliations.

\section{Submit your manuscript to a SpringerOpen ${ }^{\circ}$ journal and benefit from:}

- Convenient online submission

- Rigorous peer review

- Open access: articles freely available online

- High visibility within the field

- Retaining the copyright to your article

Submit your next manuscript at $\boldsymbol{\text { springeropen.com }}$ 